\title{
Adrenergic regulation of innate immunity: a review
}

\author{
Angela Scanzano* and Marco Cosentino \\ Center for Research in Medical Pharmacology, University of Insubria, Varese, Italy
}

The sympathetic nervous system has a major role in the brain-immune cross-talk, but few information exist on the sympathoadrenergic regulation of innate immune system. The aim of this review is to summarize available knowledge regarding the sympathetic modulation of the innate immune response, providing a rational background for the possible repurposing of adrenergic drugs as immunomodulating agents. The cells of immune system express adrenoceptors (AR), which represent the target for noradrenaline and adrenaline. In human neutrophils, adrenaline and noradrenaline inhibit migration, $\mathrm{CD} 11 \mathrm{~b} / \mathrm{CD} 18$ expression, and oxidative metabolism, possibly through $\beta$-AR, although the role of $\alpha_{1}$ - and $\alpha_{2}$-AR requires further investigation. Natural Killer express $\beta$-AR, which are usually inhibitory. Monocytes express $\beta$-AR and their activation is usually antiinflammatory. On murine Dentritic cells (DC), $\beta$-AR mediate sympathetic influence on DC-T cells interactions. In human DC $\beta_{2}$-AR may affect Th1/2 differentiation of CD4+ T cells. In microglia and in astrocytes, $\beta_{2}-A R$ dysregulation may contribute to neuroinflammation in autoimmune and neurodegenerative disease. In conclusion, extensive evidence supports a critical role for adrenergic mechanisms in the regulation of innate immunity, in peripheral tissues as well as in the CNS. Sympathoadrenergic pathways in the innate immune system may represent novel antiinflammatory and immunomodulating targets with significant therapeutic potential.

Keywords: noradrenaline, adrenaline, adrenoceptors, innate immunity, immunity of CNS

\section{Introduction}

\section{Physiology and Pharmacology of Adrenergic Pathways}

Adrenaline ("near the kidney," from Latin roots ad and renes; US: epinephrine, from the Greek roots epi and nephros, i.e., "on the kidney") belongs together with noradrenaline (the prefix "nor" standing for nitrogen öhne radikal, indicating the absence of a methyl group) to

This article was submitted to Inflammation Pharmacology, a section of the journal

Frontiers in Pharmacology

Received: 21 May 2015

Accepted: 31 July 2015

Published: 13 August 2015

Citation:

Scanzano A and Cosentino M (2015)

Adrenergic regulation of innate immunity: a review.

Front. Pharmacol. 6:171 doi: 10.3389/fphar.2015.00171

Abbreviations: DC, Dendritic cells; NK, Natural killer cells; $\gamma \delta$ T lymphocytes, Gamma Delta T lymphocytes; AR, Adrenoceptors; Th, T helper lymphocytes; LC, Locus coeruleus; cAMP, Cyclic adenosine monophosphate; CNS, Central nervous system; ILC, Innate lymphoid cells; PRR, Pattern recognition receptors; PAMP, Pathogen-associated molecular patterns; DAMP, Danger (or damage)-associated molecular patterns; TLR, Toll-like receptors; NLR, NOD-like receptors; CLR, C-type lectin receptors; RLR, RIG-I-like receptors; ALR, AIM2-like receptors; FPR, Formyl peptide receptors; gC1qR, gClq receptor; SPLUNC1, Nasal epithelial clone 1; hBD, Human $\beta$-defensin; HNP, Human neutrophil peptide; MAO, Monoamine oxidase; VMAT, Vesicular monoamine transporter; EPO, Eosinophil peroxidase; TNF, Tumor necrosis factor; SCF, Stem cell factor; MIP, Macrophage inflammatory protein; LPS, Lipopolysaccharide; IL, Interleukine; IE, Immediateearly; MMP, Matrix metalloproteinases; PKC, Protein kinase C; MHC, Major histocompatibility complex; PLC, Phospholipase C; PKA, Protein kinase A; CpG-C ODN, Type-C CpG oligodeoxynucleotides; COX, Cyclooxygenase; THP-1, Human microglia-like cells; MDSC, Myeloid-derived suppressor cells. 
catecholamines, a group of chemicals containing a catechol or 3,4-dihydroxyphenyl group and an amine function. The first step in the synthesis of Noradrenaline is the transformation of the aminoacid tyrosine in Levodopa through the enzyme tyrosine hydroxilase that is the key rate-limiting enzyme in the biosynthetic pathway of Noradrenaline.Levodopa is decaborxlated into dopamine and finally noradrenaline is synthesized from dopamine by dopamine $\beta$-hydroxylase and is converted to adrenaline by phenylethanolamine $\mathrm{N}$ methyltransferase (Figure 1). Adrenaline was isolated as pure crystalline base in 1900 by Jokichi Takamine in New Jersey and was the first hormone to be isolated in a pure state, while noradrenaline was proved in 1949 by Ulf von Euler in Stokholm to be the main sympathomimetic neurotransmitter in humans.

Noradrenaline act as neurotransmitter in the central and peripheral nervous systems. The sympathetic nervous system, through its preganglionic fibers, stimulates chromaffin cells in the adrenal glands to release into the bloodstream adrenaline ( $\sim 80 \%$ in humans) and noradrenaline ( $\sim 20 \%)$. In the brain, noradrenergic neurons are located mainly in the locus coeruleus (LC), and their axons project to hippocampus, septum, hypothalamus and thalamus, cortex and amygdala, to cerebellum, as well as to spinal cord. Brain adrenergic pathways control attention, arousal and vigilance, and regulate hunger and feeding behavior. Some central nervous system (CNS) neurons, mainly located in the medullary reticular formation, utilize adrenaline as the main neurotransmitter, possibly contributing to the modulation of eating behavior and to blood pressure regulation. In the periphery, noradrenaline is the main transmitter of sympathetic postganglionic fibers. Main direct effects of noradrenaline and adrenaline on peripheral tissues include: smooth muscle contraction in blood vessels supplying skin, kidney, and mucous membranes, stimulation of exocrine glands, smooth muscle relaxation in the gut wall, bronchi, and blood vessels supplying skeletal muscle, increases of heart rate and force of contraction, increased glycogenolysis in liver and muscle, lipolysis in adipose tissue, thermogenesis in the brown adipose tissue, modulation of the secretion of insulin and rennin (Feldman et al., 1997).

\section{Adrenergic Receptors}

The effects of noradrenaline and adrenaline are mediated by 7 transmembrane, G-protein coupled receptors called "adrenergic receptors" or "adrenoceptors" (AR) and classified in three major types- $\alpha_{1}, \alpha_{2}$, and $\beta$-each further divided into three subtypes, which are widely expressed throughout the CNS and in virtually all peripheral tissues (Ahlquist, 1948; Bylund et al., 1994).

The order of potency in the activation of these receptors by physiological ligands is noradrenaline $>$ adrenaline for the $\alpha_{1}$ and $\alpha_{2}$-AR and adrenaline $>$ noradrenaline for the $\beta$-AR.

Activation of $\alpha_{1}$-AR by adrenergic agonists induces the stimulation of a $\mathrm{Gq}$ and consequent phospholipase $\mathrm{C}$ (PLC) activation that promotes hydrolysis of phosphatidylinositol bisphosphate producing inositol trisphosphate and diacylglycerol. The results of this activation is the release of $\mathrm{Ca}^{++}$as second messenger from non-mitochondrial pools or protein kinase $\mathrm{C}(\mathrm{PKC})$ and mediating intracellular release

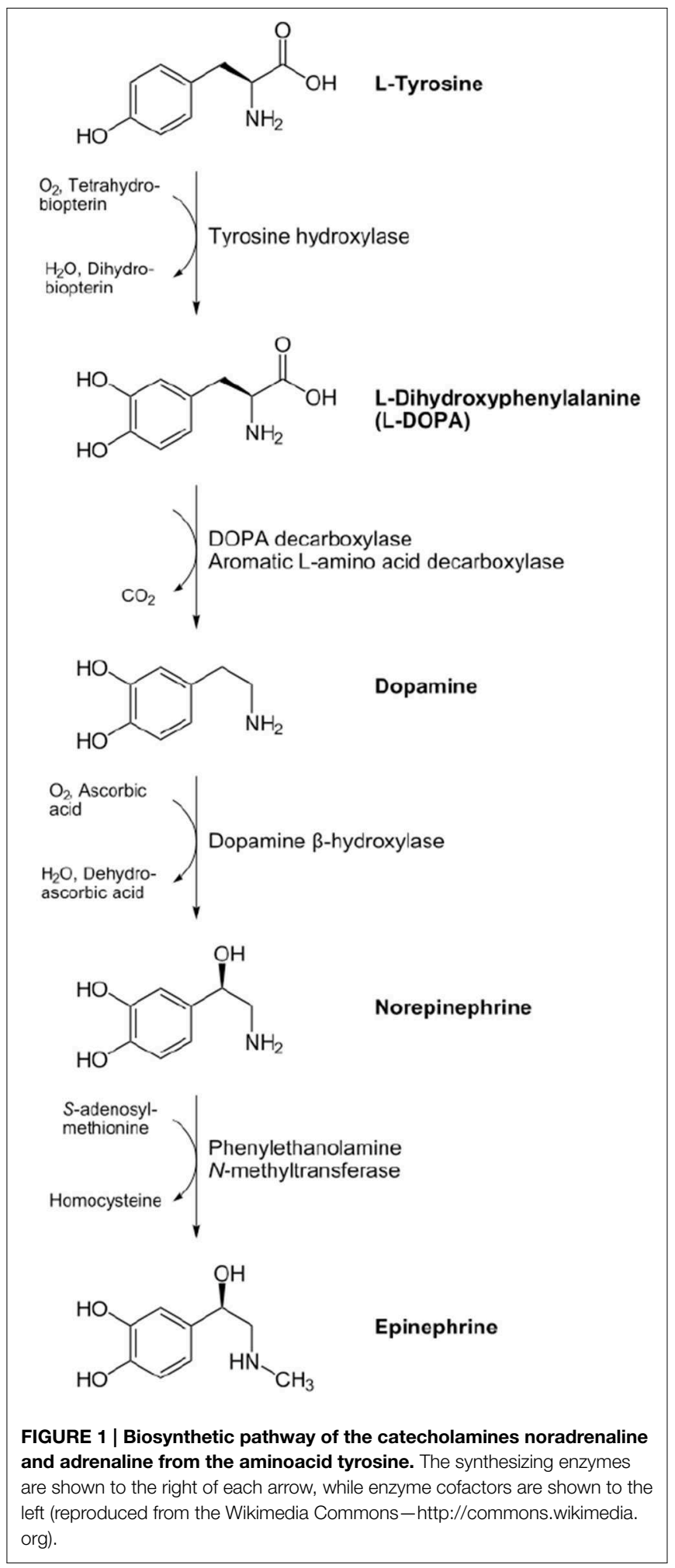

(Bylund et al., 1994). The $\alpha_{2}$-AR are considered inhibitory receptors; their activation induces the stimulation of a $\mathrm{Gi}$ resulting in adenylate cyclase inhibition and reduction of cyclic adenosine monophosphate (Bylund et al., 1994). Presynaptic autoreceptors mediating inhibition of neurotransmitter 
release are mainly $\alpha_{2}-\mathrm{AR}$, while postsynaptic $\mathrm{AR}$ include all subtypes.

$\beta$-AR are coupled to a stimulatory Gs that leads to activation of adenylate cyclase and accumulation of the second messenger cAMP. In some situations, the $\beta_{3}-\mathrm{AR}$, can be coupled to $\mathrm{Gi}$ as well as to Gs (Gauthier et al., 1996). Receptors stimulation induces the protein kinase A (PKA) activation and phosporilation of L-type $\mathrm{Ca}^{++}$channels and $\mathrm{Ca}^{++}$entry (Guimarães and Moura, 2001). The $\beta_{1}-\mathrm{AR}$ is the most important receptor that mediates cardiovascular responses to noradrenaline released from sympathetic nerve terminals and to circulating adrenaline. $\beta_{2}$-AR are primarily localized on airway smooth muscle cells and are known to be involved in bronchial muscle relaxation.

AR ligands are used as drug therapeutics in different cardiovascular diseases such as hypertension, angina pectoris, congestive heart failure, or other diseases affecting million of individuals such as asthma, depression, benign prostatic hypertrophy, and glaucoma, as well as in shock, premature labor, opioid withdrawal, and as adjunct medications in general anesthesia (Bylund et al., 1994; Perez et al.) ${ }^{1}$. Agonists of $\beta_{2}$ $\mathrm{AR}$ are employed in therapy as first line-treatment of asthma and chronic obstructive pulmonary disease. The $\beta_{3}-\mathrm{AR}$ is known to be located primarily on adipocytes (Harms et al., 1974), but at present no ligands of this receptors subtype are employed in therapy. The physiopharmacology of AR is summarized in Table 1.

\section{Adrenergic Regulation of the Immune Response: an Overview}

Together with the hypothalamic-pituitary-adrenal axis, the sympathetic nervous system represents, the major pathway involved in the cross-talk between the brain and the immune system. Sympathoadrenergic fibers innervate both primary (bone marrow and thymus) and secondary (spleen and lymph nodes) lymphoid organs, where noradrenaline and adrenaline are released from nerve varicosities and or diffuse from the bloodstream to act on AR expressed on immune cells (Elenkov et al., 2000; Straub, 2004; Marino and Cosentino, 2013).

\section{The Innate Immune System}

The innate immune system is usually considered as the first line of defense against invading microorganisms, however its contribution is increasingly emerging in several noninfectious diseases, including atherosclerosis (Chávez-Sánchez et al., 2014) and its ischemic complications (Courties et al., 2014), inflammatory bowel disease (Levine and Segal, 2013), systemic sclerosis (O’Reilly, 2014), multiple sclerosis, and other demyelinating disease (Mayo et al., 2012), neurodegenerative disease (Boutajangout and Wisniewski, 2013), and only as example, obesity (Lumeng, 2013) and diabetes (Lee, 2014) or that innate immunity play a role in tumor recognition (Marcus et al., 2014) and as a barrier to organ transplantation (Farrar et al.,

\footnotetext{
${ }^{1}$ Adrenoceptors. Last modified on 13/06/2014. Accessed on 02/09/2014., IUPHAR database (IUPHAR-DB). Available online at: http://www.iuphar-db.org/ DATABASE/FamilyMenuForward?familyId=4.
}

2013), and even in psychiatric disorders (Jones and Thomsen, 2013).

The innate immune system consists of effector molecules such as complement and antibacterial peptides as well as of effector cells. Complement is a proteolytic cascade system comprising around 35 different soluble and membrane-bound proteins, which is crucial for defense from microbial infections and for clearance of immune complexes and injured cells (Noris and Remuzzi, 2013). Antibacterial peptides are cationic peptides (i.e., with positive net charge) containing 15-45 aminoacid residues, which are both potent antibiotics usually targeting bacterial membranes as well as effective modulators of the immune response (Boman, 2003). Innate immune cells include: granulocytes (neutrophils, eosinophils, basophils, mast cells), monocytes/macrophages, dendritic cells (DC), natural killer (NK) cells, $\gamma \delta \mathrm{T}$ lymphocytes, as well as the recently described innate lymphoid cells (ILC). Immune responses in the CNS are mediated by resident microglia and astrocytes, which are innate immune cells without direct counterparts in the periphery.

Noxious stimuli alert the innate immune system through pattern recognition receptors (PRR), which can be activated by both exogenous pathogen-associated molecular patterns (PAMP) and endogenous danger (or damage)-associated molecular patterns (DAMP). PRR includes families of toll-like receptors (TLR, "toll” being the German word for "amazing" or "great"), NOD-like receptors (NLR, NOD standing for nucleotidebinding oligomerization domain), C-type lectin receptors (CLR, including mannose receptors and asialoglycoprotein receptors), RIG-I-like receptors (RLR, where RIG-I stands for retinoic acidinducible gene 1), and AIM2-like receptors (ALR, AIM-2 or "absent in melanoma 2" being part of the inflammasome and contributing to the defense against microbial DNA). Formyl peptide receptors (FPR, binding $\mathrm{N}$-formyl peptides derived from the degradation of either bacterial, or host cells) and scavenger receptors (binding oxidized or acetylated low-density lipoprotein) could be also included among PRR (Kawai and Akira, 2010; Saxena and Yeretssian, 2014).

\section{Adrenergic Modulation of the Innate Immune System}

Several excellent reviews deal with the role of sympathoadrenergic pathways in the communication between the nervous system and the immune system (Elenkov et al., 2000; Kohm and Sanders, 2001; Marino and Cosentino, 2013; Kenney and Ganta, 2014). However, most information regards adaptive immunity, and adrenergic regulation of the innate immune response is a relatively recent issue (Elenkov et al., 2000; Wrona, 2006; Flierl et al., 2008a; Marino and Cosentino, 2013). We will hereafter revise the most recent literature concerning humoral and cellular arms of the innate immune response, with specific attention to data obtained in humans and to their clinical implications.

\section{Complement}

Although AR-mediated modulation of complement-induced innate immune response has been characterized at least in 
TABLE 1 | Classification of AR (Perez et al.).

\begin{tabular}{|c|c|c|c|c|}
\hline & $\begin{array}{l}\text { Main transduction } \\
\text { mechanisms }\end{array}$ & Human tissue distribution & Physiological functions & Therapeutic drugs (indications) \\
\hline$\alpha_{1 \mathrm{~A}}$ & \multirow[t]{3}{*}{$\begin{array}{l}\mathrm{G}_{\mathrm{q}} / \mathrm{G}_{11} \text { (phospholipase } \mathrm{C} \\
\text { stimulation, calcium channel) }\end{array}$} & $\begin{array}{l}\text { Cerebral cortex, cerebellum, } \\
\text { heart, liver, predominant subtype } \\
\text { in prostate and urethra, } \\
\text { lymphocytes }\end{array}$ & $\begin{array}{l}\text { Contraction of urethral smooth } \\
\text { muscle, contraction of skeletal } \\
\text { muscle resistance arteries, } \\
\text { contraction of human } \\
\text { subcutaneous arteries }\end{array}$ & \multirow{3}{*}{$\begin{array}{l}\text { Agonists: methoxamine, methylnoradrenaline, } \\
\text { midodrine, oxymetazoline, metaraminol, } \\
\text { phenylephrine (vasoconstriction and } \\
\text { mydriasis, used as vasopressors, nasal } \\
\text { decongestants, and eye exams) } \\
\text { Antagonists: alfuzosin, doxazosin, } \\
\text { phenoxybenzamine, phentolamine, prazosin, } \\
\text { tamsulosin, terazosin, trazodone } \\
\text { (hypertension, benign prostatic hyperplasia) }\end{array}$} \\
\hline$\alpha_{1 \mathrm{~B}}$ & & $\begin{array}{l}\text { Spleen and kidney, somatic } \\
\text { arteries and veins, endothelial } \\
\text { cells, lymphocytes, osteoblasts }\end{array}$ & $\begin{array}{l}\text { Contraction of arteries and veins, } \\
\text { osteoblast proliferation }\end{array}$ & \\
\hline$\alpha_{1 D}$ & & $\begin{array}{l}\text { Cerebral cortex, aorta, blood } \\
\text { vessels of prostate, human } \\
\text { bladder, lymphocytes }\end{array}$ & $\begin{array}{l}\text { Contraction of arteries, ureteral } \\
\text { contraction }\end{array}$ & \\
\hline$\alpha_{2 A}$ & \multirow[t]{3}{*}{$\begin{array}{l}\mathrm{G}_{\mathrm{i}} / \mathrm{G}_{\mathrm{o}} \text { (adenylate cyclase } \\
\text { inhibition, potassium channel, } \\
\text { calcium channel, phospholipase } \\
\text { A2 stimulation) }\end{array}$} & $\begin{array}{l}\text { Brain }>\text { spleen }>\text { kidney }>\text { aorta } \\
=\text { lung }=\text { skeletal muscle }>\text { heart } \\
=\text { liver }\end{array}$ & $\begin{array}{l}\text { Presynaptic inhibition of } \\
\text { noradrenaline release, } \\
\text { hypotension, sedation, } \\
\text { analgesia, hypothermia }\end{array}$ & \multirow{3}{*}{$\begin{array}{l}\text { Agonists: dexmedetomidine, medetomidine, } \\
\text { romifidine, clonidine, brimonidine, } \\
\text { detomidine, lofexidine, xylazine, tizanidine, } \\
\text { guanfacine, amitraz (antihypertensives, } \\
\text { sedatives and treatment of opiate } \\
\text { dependence and alcohol withdrawal } \\
\text { symptoms) } \\
\text { Antagonists: phentolamine, yohimbine, } \\
\text { idazoxan, atipamezole, trazodone, mianserin, } \\
\text { mirtazapine (aphrodisiac, antidepressants, } \\
\text { reversal of } \alpha_{2} \text {-AR agonist-induced sedation) }\end{array}$} \\
\hline$\alpha_{2 B}$ & & $\begin{array}{l}\text { Kidney }>>\text { liver }>\text { brain }=\text { lung }= \\
\text { heart }=\text { skeletal muscle (also } \\
\text { reported in aorta and spleen) }\end{array}$ & Vasoconstriction & \\
\hline$\alpha_{2 C}$ & & $\begin{array}{l}\text { Brain = kidney (also reported in } \\
\text { spleen, aorta, heart, liver, lung, } \\
\text { skeletal muscle) }\end{array}$ & $\begin{array}{l}\text { Presynaptic inhibition of } \\
\text { noradrenaline release }\end{array}$ & \\
\hline$\beta_{1}$ & \multirow[t]{3}{*}{$\begin{array}{l}\mathrm{G}_{\mathrm{S}} \text { (adenylate cyclase } \\
\text { stimulation) }\end{array}$} & $\begin{array}{l}\text { Brain, lung, spleen, heart, kidney, } \\
\text { liver, muscle }\end{array}$ & $\begin{array}{l}\text { Increase of cardiac output (heart } \\
\text { rate, contractility, automaticity, } \\
\text { conduction), renin release from } \\
\text { juxtaglomerular cells, lipolysis in } \\
\text { adipose tissue }\end{array}$ & $\begin{array}{l}\text { Agonists Dobutamine, isoprenaline, } \\
\text { noradrenaline (bradycardia, heart failure, } \\
\text { cardiogenic shock) Antagonists Metoprolol, } \\
\text { atenolol, bisoprolol, propranolol, timolol, } \\
\text { nebivolol (cardiac arrhythmia, congestive } \\
\text { heart failure, glaucoma, myocardial infarction, } \\
\text { migraine prophylaxis) }\end{array}$ \\
\hline$\beta_{2}$ & & $\begin{array}{l}\text { Brain, lung, lymphocytes, skin, } \\
\text { liver, heart }\end{array}$ & $\begin{array}{l}\text { Smooth muscle relaxation, } \\
\text { striated muscle tremor, } \\
\text { glycogenolysis, increased mass } \\
\text { and contraction speed, increase } \\
\text { of cardiac output, increase of } \\
\text { acqueous humor production in } \\
\text { eye, dilatation of arteries, } \\
\text { glycogenolysis and } \\
\text { gluconeogenesis in liver, insulin } \\
\text { secretion, broncodilation }\end{array}$ & $\begin{array}{l}\text { Agonists: (short-acting) salbutamol } \\
\text { (albuterol), levosalbutamol (levalbuterol), } \\
\text { terbutaline, pirbuterol, procaterol, } \\
\text { metaproterenol, fenoterol, bitolterol mesylate, } \\
\text { ritodrine, isoprenaline, (long-acting) } \\
\text { salmeterol, formoterol, bambuterol, } \\
\text { clenbuterol, (ultra-long-acting) indacaterol } \\
\text { (asthma, other effects: vasodilation in muscle } \\
\text { and liver, relaxation of uterine muscle, and } \\
\text { release of insulin) Antagonists: butoxamine, } \\
\text { timolol, propranolol (glaucoma, heart attacks, } \\
\text { hypertension, migraine headache; } \\
\text { investigational: stage fright, post-traumatic } \\
\text { stress disorder) }\end{array}$ \\
\hline$\beta_{3}$ & & $\begin{array}{l}\text { Adipose tissue, gall bladder }> \\
\text { small intestine }>\text { stomach, } \\
\text { prostate }>\text { left atrium }>\text { bladder } \\
\text { (also reported in brown adipose } \\
\text { tissue and endothelium of } \\
\text { coronary microarteries) }\end{array}$ & $\begin{array}{l}\text { Lipolysis, thermogenesis, } \\
\text { relaxation of miometrium and } \\
\text { colonic smooth muscle cells, } \\
\text { vasodilatation of coronary } \\
\text { arteries, negative cardiac } \\
\text { inotropic effect }\end{array}$ & $\begin{array}{l}\text { Agonists: amibegron (investigational: } \\
\text { antidepressant, anxiolytic), solabegron } \\
\text { (overactive bladder, irritable bowel syndrome) } \\
\text { Antagonists: SR } 59230 \mathrm{~A}\end{array}$ \\
\hline
\end{tabular}

animal models (Flierl et al., 2008a), nearly no information is available regarding any direct effect of adrenergic pathways on complement activity.

In vitro, adrenaline and noradrenaline may enhance in monocytes the synthesis of several complement components (such as C2, C3, C4, C5, factor B, properdin, beta $1 \mathrm{H}$, and C3b inactivator), possibly through the activation of $\alpha_{1}$-AR
(Lappin and Whaley, 1982). Adrenaline has also been reported to inhibit C5-convertase generation from C3-convertase stabilized by nickel ions (Kozlov and Lebedeva, 1998), and to inhibit the covalent binding of the nascent $\mathrm{C} 4 \mathrm{~b}$ fragment of the human complement component to IgG (Kozlov et al., 2000), however the physiological relevance of such effects was not investigated. In COS-7 transfected cells, it was shown that 
gC1qR (i.e., gC1q receptor, gC1q binding protein, p32, p33), a multifunctional cellular protein that interacts with components of the complement, kinin, and coagulation cascades as well as with select microbial pathogens, may bind with the carboxylterminal cytoplasmic domain of the $\alpha_{1 B}-A R$ (Xu et al., 1999).

Early studies in rodents suggested that $\alpha$-AR stimulation might result in increased secretion with saliva of a potent kallikrein-like anticomplementary factor (Wallace et al., 1976). In rats evidence has also been provided that the $\beta$-AR agonist isoprenaline reduces the clearance function of complement receptors on Kupffer cells, an effect which is sensitive to $\beta$-AR antagonism (Loegering and Commins, 1988), and that adrenaline may affect complement activity, both acutely (reduction followed by increase and then return to normal values in $2 \mathrm{~h}$ ) and in the long term (increase $24 \mathrm{~h}$ after administration and peak after 2-3 days), however the specific contribution of AR subtypes remains to be established (Vasin and Kuznetsova, 1995). Nonetheless, another study in rats reported no effect of adrenaline (infused together with corticosterone and glucagon) on liver synthesis of albumin, complement component C3, and alpha 1-acid glycoprotein (Pedersen et al., 1989). Remarkably, it has been recently shown that the complement anaphylatoxin C5a may induce cell apoptosis in adrenal medulla following cecal ligation and puncture-induced sepsis in rats, as well as apoptosis of pheochromocytoma PC12 cells in vitro, resulting in impaired production of noradrenaline and dopamine (Flierl et al., 2008b), revealing a novel interaction between adrenergic pathways and the complement system.

Complement proteins may also affect brain adrenergic pathways. Indeed, early reports suggest that $\mathrm{C} 5 \mathrm{a}$ might activate $\alpha$-AR in the hypothalamus, possibly explaining the neuropsychiatric symptoms sometimes associated with immune complex diseases affecting the CNS (Williams et al., 1985). Actually, C5a in the hypothalamus may act presynaptically, resulting in noradrenaline release through the activation of a specific C5a/C5ai receptor (Schupf et al., 1989).

\section{Antibacterial Peptides}

Evidence regarding an interplay between adrenergic pathways and antibacterial peptides is recent and still fragmentary, nonetheless the few available information supports its relevance. For instance, it has been reported that the $\beta$-AR agonists albuterol and formoterol may increase the antimicrobial protein short palate, lung, and nasal epithelial clone 1 (SPLUNC1) (but not $\beta$-defensin-2/hBD-2) in normal and asthma airway epithelial cells, resulting in reduced Mycoplasma pneumoniae infection, and interleukin (IL)-13 attenuates such effects, decreasing SPLUNC1 and $\beta$-AR expression (Gross et al., 2010). A $\beta$ AR-dependent mechanism seems to be involved also in the psychological stress-induced decline in both cathelicidin and human $\beta$-defensin (hBD)-3 expression in the skin of mice. The antimicrobial peptide catestatin increased after short-term stress, but then began to decline with more sustained stress. In cultured keratinocytes, glucocorticoids downregulated catestatin expression, but $\beta$-AR blockade increased catestatin, as well as cathelicidin and hBD3 (Martin-Ezquerra et al., 2011). Human neutrophil peptides (HNP) 1-3 are expressed also in the synovial lining and adjacent sublining area (but not in deeper layers of synovial tissue) in both rheumatoid arthritis and osteoarthritis subjects, and their expression is concentration-dependently inhibited by noradrenaline (Riepl et al., 2010). Adrenergic agents may therefore enhance or inhibit the expression of antibacterial peptides, depending on the specific circumstances, however the factors contributing to the specific effects have been not yet clarified.

Antibacterial peptides may also affect the response of tissues to adrenergic stimulation. Recently, it has been reported that $\alpha$ defensin-1/HNP1 has relaxing effects on adrenergic contractions of rat detrusor muscles, possibly through NF- $\mathrm{B}$ pathways (Lee et al., 2011).

Finally, adrenaline and noradrenaline have been shown to downregulate S. Typhimurium virulence gene expression, increasing its sensitivity to the antimicrobial peptide LL-37 (Spencer et al., 2010).

\section{Cells}

\section{Granulocytes}

Granulocytes (also known as polymorphonuclear leukocytes) are named after the presence of intracellular granules. Granulocytes are currently divided into different types, based on their staining characteristics: neutrophils (the most abundant, representing $40-80 \%$ of total leukocytes in normal conditions), eosinophils, basophils, and mast cells. Neutrophils are the major cellular arm of the innate immune system. They are phagocytic cells which are recruited to sites of infection to kill pathogens, however it is increasingly evident that they also play a key role in progression of non-infectious disease as well as in conditions characterized by chronic inflammation (Mócsai, 2013; Mayadas et al., 2014). Eosinophils have a prominent role in allergic diseases and inflammatory responses against helminthic parasites, and are involved in diseases involving mucosal surfaces, (e.g., allergic asthma, atopic dermatitis, and gastrointestinal disorders) (Kita, 2013). Basophils are similar to tissue-resident mast cells and their main function is the protection against infections with parasites, including ticks, and helminths (Karasuyama and Yamanishi, 2014). Finally, mast cells are tissue-resident granulocytes mainly located at the interface with the external environment. They contain granules rich in histamine and heparin, and their main roles are in allergy, wound healing, defense against pathogens, as well as in antitumor immunity (da Silva et al., 2014).

Adrenergic modulation of granulocytes has been examined mainly in neutrophil, nonetheless available evidence suggests that adrenergic agents may profoundly affect all granulocyte subtypes.

\section{Neutrophils}

The $\beta$-AR agonist isoprenaline inhibits the respiratory burst in human neutrophils (Nielson, 1987), an effect which has been confirmed in later studies and attributed to $\beta_{2}$-AR (Brunskole Hummel et al., 2013). IL-8 production however seems to be not sensitive to adrenaline, which only slightly reduces the expression of the adhesion molecules CD15, CD44, and CD54, and only at very high concentrations ( $1 \mathrm{mM}$ ) (Wahle et al., 2005). Recently however the in vitro adhesion of neutrophils to endothelial cells 
was shown to be inhibited by adrenaline, an effect likely due to $\beta$ AR activation (Trabold et al., 2010). Desensitization of $\beta$-AR may occur after activation of the neutrophil respiratory burst (Vago et al., 1990), and neutrophils from elderly subjects may have decreased $\beta$-AR responsiveness (Cotter and O'Malley, 1983).

Ligand binding studies suggest that on average 1700-2200 $\beta$ AR are expressed on neutrophil membranes (Pohl et al., 1991; Schwab et al., 1993), while excluding the existence of $\alpha_{2}$-AR (Musgrave and Seifert, 1994). We have recently shown that human neutrophils express mRNA for all $\alpha$ - (with the only exception of $\left.\alpha_{2 B^{-}}\right)$and $\beta$-AR, in the following order: $\beta_{3}>\beta_{2}>$ $\alpha_{1 \mathrm{~A}}>\alpha_{1 \mathrm{~B}} \sim \alpha_{2 \mathrm{~A}} \sim \beta_{1}=\alpha_{1 \mathrm{D}}=\alpha_{2 \mathrm{C}}$ and that exposure of cells to IL-8, a potent proinflammatory CXC-chemokine that promotes neutrophil chemotaxis and degranulation, increases mRNA levels of all AR, and that adrenaline, probably through the involvement of $\beta$-AR, profoundly affects neutrophil function (Scanzano et al., 2015).

Conditions reported to be associated with decreased $\beta$ AR expression on circulating neutrophils include: essential hypertension (Corradi et al., 1981), juvenile type I diabetes mellitus (Schwab et al., 1993), as well as strenuous physical exercise (Ratge et al., 1988; Fragala et al., 2011). Increased $\beta$-AR expression has been reported in post-traumatic stress disorder (Gurguis et al., 1999).

Circumstantial evidence suggests that neutrophils may also synthesize and release catecholamines. Noradrenaline and adrenaline (as well as dopamine and their major metabolites) have been identified human neutrophils (Cosentino et al., 1999), which may also contain some catecholamine-degrading enzymes, such as monoamine oxidase (MAO), possibly of the B type (Balsa et al., 1989). Indeed, the MAO inhibitor pargyline may lead at least in vitro to increased catecholamine levels in human neutrophils (Cosentino et al., 1999). Interestingly, exposure of rodent cells to lipopolysaccharide (LPS) results in catecholamine release together with induction of catecholaminegenerating and degrading enzymes, and blockade of $\alpha_{2}$-AR or pharmacological inhibition of catecholamine synthesis may suppress (while $\alpha_{2}$-AR agonism or inhibition of catecholaminedegrading enzymes enhances) lung inflammation in rodent models of acute lung injury. Adrenalectomized animals show even enhanced catecholamine release from phagocytes as well as enhanced expression of catecholamine-synthesizing enzymes in these cells. Such results have been explained suggesting that in rodent phagocytes noradrenaline and adrenaline possibly activate $\mathrm{NF} \kappa \mathrm{B}$ resulting in enhanced release of tumor necrosis factor (TNF)- $\alpha$, IL- $1 \beta$ and IL-6, and in the subsequent amplification of acute inflammation via $\alpha_{2}$-AR (Flierl et al., 2007, 2009). We recently identified in human neutrophils the presence mRNA for tyrosine hydroxylase, the rate-limiting enzyme in the synthesis of catecholamines, as well as for the vesicular monoamine transporter (VMAT) 2 (but not 1) (Scanzano et al., 2015).

\section{Eosinophils}

The role of adrenergic pathways in eosinophils has been studied mainly in relation to their role in allergic diseases and inflammation, with particular regard to the respiratory tract. Several studies indeed deal with the effects on eosinophils exerted by $\beta_{2}$-AR agonists used as bronchodilators, however most of those studies do not provide clear evidence that any effects are actually due to AR-operated pathways (e.g., due to the absence of experiments with $\mathrm{AR}$ antagonists). This is a relevant issue, since many effects exerted by $\beta_{2}$-AR agonists may actually occur through $\beta$-AR-independent mechanisms (Tachibana et al., 2002).

Early studies in humans examined the response of circulating eosinophils to noradrenaline, adrenaline, and emotional stress (Humphreys and Raab, 1950). In healthy subjects, the fall in circulating eosinophils following adrenaline injection, as well as the rise induced by the administration of $\beta$-AR antagonists is well characterized (Koch-Weser, 1968). Several decades later however $\beta$-AR detected on eosinophils, as well as on mast cells, macrophages, and neutrophils, were still considered of limited functional importance, due to rapid tachyphylaxis (Barnes, 1993).

Binding and functional data support the existence in eosinophils from patients with eosinophilia and from the peritoneal cavity of guinea pigs of $\beta$-AR possibly of the $\beta_{2}$ subtype, coupled to adenylate cyclase, but apparently not involved in oxidative metabolism or degranulation (Yukawa et al., 1990). A few years later however another study showed that $\beta_{2}$-AR may inhibit stimulated leukotriene $C 4$ secretion and eosinophil peroxidase (EPO, an eosinophil granule basic protein) release in purified human peripheral blood eosinophils (Munoz et al., 1994). Further evidence for the functional relevance of $\beta$ AR in eosinophils is provided by results obtained in a model of airway inflammation induced in anesthetized rats by injecting substance $P$ or bradykinin intravenously, where activation of $\beta_{2}$ AR by the $\beta_{2}$-AR agonist formoterol was shown to reduce the amount of plasma leakage and also the number of neutrophils and eosinophils that adhered to the vascular endothelium at sites of inflammation, an effect which could be antagonized by the $\beta_{2}$-AR antagonist propranolol (Bowden Sulakvelidze and McDonald, 1994). Finally, EPO has been shown to decrease $\beta$ AR density on guinea pig lung membranes (Motojima et al., 1992). No information is available regarding the existence and the functional relevance on eosinophils of $\alpha-A R$ as well as of $\beta_{1-}$ or $\beta_{3}$-AR.

\section{Basophils}

Clonidine, an $\alpha_{2}$-AR agonist used as antihypertensive, reduced stimulated secretion of histamine in human basophils, however the effect was inhibited by histamine receptor $\mathrm{H} 2$ blockers and not by $\alpha_{1}-\mathrm{AR}$ or $\alpha_{2}$-AR antagonists, thus a contribution of $\alpha_{2}-\mathrm{AR}$ could be ruled out (Miadonna et al., 1989). Recently, the antigenic activation of basophils isolated from the blood of atopic donors was shown to be decreased by adrenaline, an effect which was reduced by the $\beta$-AR antagonist propranolol (Mannaioni et al., 2010).

\section{Mast cells}

Both ligand-binding studies and functional data suggest that IgEmediated histamine release from mast cells may be inhibited by $\beta$-AR (Masini et al., 1982). Desensitization of $\beta$-AR on human lung mast cells may occur after prolonged exposure to $\beta$-AR 
agonists like isoprenaline, an effect which is prevented by $\beta$ AR antagonists (Chong et al., 1995). Pharmacological evidence suggests that $\beta$-AR mediating inhibition of histamine release from human lung mast cells as well as from mast cells cultured from human peripheral blood are $\beta_{2}$-AR (Chong et al., 2002; Wang and Lau, 2006). The $\beta_{2}-\mathrm{AR}$ are also responsible in mast cells isolated from human intestinal mucosa for the inhibition exerted by adrenaline, noradrenaline, and salbutamol on IgE receptor-dependent release of histamine, lipid mediators, and TNF- $\alpha$, as well as on proliferation, migration and adhesion to fibronectin and human endothelial cells (Gebhardt et al., 2005). Stem cell factor (SCF), the key human mast cell growth factor which primes mast cells for mediator release and markedly increases in asthmatic airways, profoundly reduces $\beta_{2}$-ARmediated inhibition of histamine release from human lung mast cells, possibly through SCF-dependent phosphorylation of Tyr350 on the $\beta_{2}$-AR with immediate uncoupling of the receptor followed by receptor internalization (Cruse et al., 2010). At least one review exists about $\beta_{2}$-AR in human lung mast cells, including the influence of genetic polymorphisms in the $\beta_{2}$-AR gene (Kay and Peachell, 2005). A report also exists suggesting the existence of $\alpha_{1}$-AR in mast cells (Schulze and Fu, 1996) while recently Prey and coworkers shows that human mast cells are positive for the staining for both $\beta_{1}$-AR and $\beta_{2}$-AR while were negative for $\beta_{3}$-AR (Prey et al., 2014).

\section{Monocytes/macrophages}

Between myeloid cells, monocyte/macrophages show different phenotypes, homeostatic turnover and functions in different tissues (Geissmann et al., 2010). Monocytes have long been considered as a developmental intermediate between bone marrow precursors and tissue macrophages. Monocytes and macrophages, together with DC, constitute the mononuclear phagocyte system which plays a key role maintaining tissue integrity during development and its restoration after injury, as well as the initiation and resolution of innate and adaptive immunity. Originally defined as bone marrow-derived myeloid cells circulating in the blood as monocytes and populating tissues as macrophages in the steady state and during inflammation, they have different phenotype, homeostatic turnover, and function in different tissues (Geissmann et al., 2010). Monocytes carry out specific effectors' functions during inflammation (De Kleer et al., 2014) and are usually classified in CD14++CCCD16- classical human monocytes or intermediates CD14++CCCD16+ cells.

Monocytes are endowed with chemokine receptors and PRR that modulate their migration from blood to tissues, where they produce proinflammatory cytokines and phagocyte cells and toxic molecules. Differentiation into DC or macrophages occurs during inflammation, and possibly in the steady state, depending on the inflammatory and PAMP/DAMP microenvironment (Serbina et al., 2008; Auffray et al., 2009).

Macrophages are resident phagocytic cells contributing to tissue homeostasis through clearance of apoptotic cells and production of growth factors. Macrophages are equipped with a broad range of pathogen recognition receptors that make them efficient at phagocytosis and induce production of inflammatory cytokines. Different subsets of macrophages occur in the various tissues (including liver Kupffer cells, lung alveolar, splenic and peritoneal macrophages, dermal macrophages). Microglial cells are resident macrophages in the CNS. The specific origins and functions of all these subsets however still await thorough investigation (Yona et al., 2013). Macrophages are also major players in major disease such as cardiovascular disease (Swirski and Nahrendorf, 2013), cancer (Biswas and Mantovani, 2010), diabetes (Cnop et al., 2005).

The expression of $\beta$-AR on human monocytes has been documented by both ligand binding and flow cytometric studies, which also suggested that their density may be affected by physical exercise (Ratge et al., 1988; Fragala et al., 2011). Receptor desensitization has been reported in human monocytes at least in vitro after prolonged $\beta_{2}$-AR stimulation, possibly through upregulation of CAMP phosphodiesterase activity (Manning et al., 1996).

The functional consequences of $\beta$-AR activation on human monocytes is usually antiinflammatory and immunosuppressive and includes: inhibition of oxygen radicals production (Schopf and Lemmel, 1983) upregulation of TNF receptors and inhibition of TNF (Guirao et al., 1997), reduction of C. albicans phagocytosis (Borda et al., 1998), inhibition of LPS-induced macrophage inflammatory protein-1 $\alpha$ (MIP-1 $\alpha$ ) (Li et al., 2003), as well as of LPS-induced IL-18 and IL-12 production (Mizuno et al., 2005). Thus, while noradrenaline and adrenaline may have antiinflammatory effects on human monocytes, reversal of their effects may result proinflammatory. As a consequence, the use of $\beta_{2}$-AR agonists has been suggested to be possibly beneficial in the treatment of sepsis through inhibiting LPS-elicited IL-18 (Mizuno et al., 2005), while recently the $\beta_{2}$-AR antagonist propranolol has been shown to reduce circulating immunosuppressive M2b monocytes in severely burned children, suggesting a role for this drug in severely burned patients to reduce their susceptibility to opportunistic infections (Kobayashi et al., 2011). Adrenergic modulation of monocytes may also contribute to explain the increased risk of viral infections following highly stressful events (e.g., herpes simplex virus type- 1 and varicella zoster virus), due to activation of the sympathetic nervous system. For instance, catecholamines directly stimulate the human cytomegalovirus immediate-early (IE) enhancer/promoter in monocytic cells via $\beta_{2}-\mathrm{AR}$, possibly leading to the development of an active human cytomegalovirus infection in latently infected patients (Prösch et al., 2000).

Adrenergic pathways in human monocytes may nonetheless result also in proinflammatory effects. Adrenaline may indeed increase monocyte attachment to laminin as well as oxidizedlow density lipoprotein phagocytosis, two effects which both may be proinflammatory and atherogenic (Sarigianni et al., 2011). In particular, activation of $\beta$-AR have been shown, under certain conditions (e.g., in unstimulated cells), to lead to proinflammatory responses in monocytes, including: increased production of IL-18 (Takahashi et al., 2003), upregulation of IL-4-induced CD23 (low affinity IgE receptor/Fc epsilon RII) expression (Mencia-Huerta et al., 1991), and potentiated IgE/anti-IgE-induced production of IL-6 (Paul-Eugène et al., 1992, 1994), IgE (Paul-Eugène et al., 1993), increased generation of superoxide anion, nitric oxide, and TxB2 (Paul-Eugène et al., 
1994). LPS- or IL-1-stimulated human monocytes exposed to $\beta_{2}$ AR agonists may produce more antiinflammatory IL-10 as well as pro-inflammatory IL-8 (Kavelaars et al., 1997). Adrenaline may upregulate the surface expression of L-selectin (Rainer et al., 1999), and noradrenaline and adrenaline may increase matrix metalloproteinases (MMP)- 1 in both circulating monocytes and monocyte-derived macrophages (Speidl et al., 2004). The $\beta$-AR agonist isoprenaline may decrease the response to LPS but per se result in increased phorbol ester-induced production of TNF$\alpha$, IL-12, and nitric oxide (Szelenyi et al., 2006). Isoprenaline may also increase LPS-induced production of IL-1 $\beta$, possibly through the activation of $\beta_{1}-\mathrm{AR}$, which were directly identified by immunoblot techniques as well as by radioligand binding studies in the monocytic cell line THP-1 (Grisanti et al., 2010). Recently, $\beta_{1}$-AR autoantibodies isolated from the sera of heart failure patients were shown to cause (TNF- $\alpha$ ) secretion from the murine macrophage-like cell line RAW264.7 (Du et al., 2012).

Early pharmacological evidence suggested the occurrence of $\alpha$-AR in human monocytes enhancing the synthesis of complement components (Lappin and Whaley, 1982). Culturing human circulating monocytes with dexamethasone or the $\beta_{2}$ $\mathrm{AR}$ agonist terbutaline may indeed trigger the expression of $\alpha_{1 B^{-}}$and $\alpha_{1 D^{-}}$AR mRNA (Rouppe van der Voort et al., 1999). LPS may result in a similar effect, possibly through the activation of ERK-2 (Rouppe van der Voort et al., 2000). The proinflammatory cytokines TNF- $\alpha$ and IL- $1 \beta$ respectively upregulate and reduce $\alpha_{1 \mathrm{~B}}$ - and $\alpha_{1 \mathrm{D}}-\mathrm{AR}$ mRNA in the human THP-1 monocytic cell line (while IL-6 and IL-8 seem to be ineffective) (Heijnen et al., 2002). Recently, on monocytes a homogenous $\alpha_{1 \mathrm{~B}}$-AR subtype population was identified, which changed to a heterogeneous receptor subtype expression pattern when differentiated to macrophages. The agonist phenylephrine synergistically increased LPS-induced IL- $1 \beta$ production and this effect was blocked in the presence of a selective $\alpha_{1}$-AR antagonist as well as of inhibitors of PKC, suggesting the occurrence on human monocytes of $\alpha_{1}$-AR mediating proinflammatory responses (Grisanti et al., 2011). Differentiation of human monocytes into macrophages may result, at least in vitro, in loss of $\beta$-AR responsiveness despite a functional adenylyl cyclase system (Baker and Fuller, 1995). Expression of $\beta$-AR on human macrophages is actually regulated upon activation in a stimulusdependent manner, thus that changes in receptor number may occur in different states of cell maturation and function (Radojcic et al., 1991). Remarkably, as human monocytes adhere to surfaces and begin differentiation into macrophages, they may lose their surface $\beta_{2}$-AR and hence become insensitive to the inhibitory effects of $\beta_{2}$-AR agonists on LPS-induced TNF- $\alpha$ production, an observation which has been related to the lack of antiinflammatory effect of $\beta_{2}$-AR agonists on alveolar macrophages or in clinical asthma (Ezeamuzie et al., 2011). Activation of $\beta_{2}$ AR may inhibit the production of TNF- $\alpha$ and of IL- 6 and increase the production of IL-10 in PMA-differentiated U937 human macrophages (Izeboud et al., 1999), however care should be exerted when using these cells to study the physiopharmacology of $\beta$-AR in human monocytes/macrophages, since $\beta_{2}-\mathrm{AR}$, which are the main subtype of $\beta$-AR expressed by these cells, exhibit lower expression on undifferentiated (monocytes) than in PMA-differentiated U937 (macrophages) (Izeboud et al., 1999). Quite interestingly, it has been proposed that in severe sepsis priming via gut-derived noradrenaline may contribute to increased release in pro-inflammatory cytokines from Kupffer cells, ultimately leading to organ dysfunction. Such an effect, which has been tentatively defined "sympathetic excitotoxicity in sepsis," could be mediated $\alpha_{2}$-AR on Kupffer cells (Miksa et al., 2005). Recently, in a porcine model of wound healing, both macrophage infiltration and angiogenesis were initially decreased, whereas dermal fibroblast function was impaired after treatment with $\beta_{2}$-AR agonists, suggesting the potential of these drugs to improve skin scarring (Le Provost and Pullar, 2015). Interestingly, human monocyte-derived macrophages of stressed subjects displayed decreased superoxide anion-responses after stress, in direct correlation with higher plasma noradrenaline, and noradrenaline-treated cells showed reduced superoxide anion-production, an effect blocked by prior incubation with the $\alpha$-AR antagonist phentolamine (Kuebler et al., 2013). Similarly, evidence about a negative effect of stress was recently shown in models of tumor in which increased levels of catecholamines contributes to the recruitment of macrophages and to the increased activation of these cells in the tumor environment (Armaiz-Pena et al., 2015). In addition negative effects were elucidated by the sympathetic activation on cancer progression. For example, metastasis in breast cancer, in mouse, was more pronounced after stress and this effects were mimicked by $\beta 2$-AR stimulation (Sloan et al., 2010).

Finally, it has been reported that, at least in vitro, $\alpha_{2}$-AR stimulation of type A (macrophage-like) and B (fibroblastlike) synoviocytes produced an increase and a decrease in the respective cell number, probably through Gi-coupled PLC activation and the resulting stimulation of the PKC betaII/MAP kinase (Mishima et al., 2001), providing preliminary evidence for a role of $\alpha_{2}$-AR regulating local innate immunity in synovial tissues.

In summary, consistent evidence supports the occurrence of $\beta$-AR on human monocytes/macrophages: $\beta_{2}$-AR are usually regarded as mainly antiinflammatory, although under certain conditions they can result in proinflammatory effects, while recent evidence suggests also the occurrence of $\beta$-AR (possibly $\beta_{1}$-AR)-mediated proinflammatory responses (Grisanti et al., 2010). Alpha-AR can also occur upon appropriate stimulation and may mediate both pro- and antiinflammatory responses, but defining their functional role still requires careful investigation.

According to evidence obtained in rodent cells, monocytes/macrophages may also produce and utilize noradrenaline and adrenaline as local transmitters. Indeed, Spengler et al. (1994) showed in mouse peritoneal macrophages stimulated with LPS that the $\beta$-AR selective antagonist propranolol increased (and the $\alpha_{2}$-AR selective antagonist idazoxan decreased) TNF- $\alpha$ production. In the same study, the presence of intracellular noradrenaline was also reported and interpreted as an evidence supporting the existence of an adrenergic autocrine loop, possibly even more pronounced in macrophages obtained from rats with streptococcal-cellwall-induced arthritis (Chou et al., 1998). Further support to the possibility that macrophages may produce endogenous 
catecholamines has been provided by Nguyen et al. (2011), who showed that exposure of mice to cold temperature rapidly promoted alternative activation of adipose tissue macrophages, which secreted catecholamines to induce thermogenic gene expression in brown adipose tissue and lipolysis in white adipose tissue. Absence of alternatively activated macrophages impaired metabolic adaptations to cold, whereas administration of IL-4 increased thermogenic gene expression, fatty acid mobilization, and energy expenditure, all in a macrophage-dependent manner (Nguyen et al., 2011). Finally, it should be mentioned that MAO type A is expressed in human monocytes in particular after incubation with IL-4, and upregulation of its expression may contribute in switching naive monocytes into a resolving phenotype, indirectly highlighting another potential role for endogenous adrenergic pathways in these cells (Chaitidis et al., 2004, 2005).

\section{Dendritic Cells}

DC are specialized antigen-processing and presenting cells, with high phagocytic activity as immature cells and high cytokine producing capacity as mature cells. DC circulate in blood and migrate from tissues to lymphoid organs, regulating $\mathrm{T}$ cell responses both in the steady-state and during infection (Mellman and Steinman, 2001; De Kleer et al., 2014). Remarkably, DC found in the epidermis are the Langerhans cells, which derive from the bone marrow, under steady-state conditions are maintained locally, but during skin inflammation may be replaced by blood-borne progenitors (Merad et al., 2002).

Few information exists regarding adrenergic pathways in human DC. In CD40-stimulated human DC, activation of $\beta_{2}$-AR increases intracellular cAMP and inhibits IL-12 production, resulting in inhibition of Th1 and promotion of Th2 differentiation (Panina-Bordignon et al., 1997). In human DC obtained from cord blood CD34+ precursor cells, noradrenaline acting through $\beta_{2}-\mathrm{AR}$ and increased cAMP inhibits LPSstimulated production of IL-23, IL-12 p40, TNF- $\alpha$, and IL-6 without affecting IL-10 (Goyarts et al., 2008). This response is similar to that obtained in mouse skin DC (Maestroni, 2005, 2006), thus suggesting that noradrenaline may regulate human skin DC function resulting in decreased Th1 differentiation of $\mathrm{CD} 4+\mathrm{T}$ cells. Indirect evidence for adrenergic regulation of human DC comes also from a study showing in 18 professional athletes a correlation between the increase of peripheral blood DC after intensive physical activity and serum adrenaline and noradenaline levels (as well as with the extent of heart rate elevation during exercise) (Suchánek et al., 2010). Recently, adrenaline was shown to inhibit migration of human DC through $\beta_{1}$-AR signaling through arrestin2-PI3K-MMP9/CCR7 (Yang et al., 2013) and that DC functions are strongly affected by catecholamines (probably $\beta_{2}$-AR mediated) that induces a profound suppression of the production of proinflammatory cytokines (Nijhuis et al., 2014).

Most of the information so far available regarding adrenergic pathways in DC has been obtained in murine DC, where AR mediate sympathetic nervous system influences on DC-T cells interactions contributing to the shaping of the appropriate adaptive immune response (reviewed by Maestroni, 2005, 2006). Both $\alpha_{1}$ - and $\beta_{2}-\mathrm{AR}$ are expressed on murine DC: $\alpha_{1}-\mathrm{AR}$ stimulate DC migration, which on the contrary is inhibited by $\beta_{2}$-AR. Noradrenaline decreases IL-12 and increases IL10 production in both skin and bone marrow-derived DC stimulated with bacterial TLR agonists and, as a consequence, DC-induced $\mathrm{T}$ helper (Th) 1 priming is impaired. Such observations may explain how reduced noradrenaline activity in the skin may promote contact sensitizers-induced Th1 responses (Maestroni, 2004). Noradrenaline also activates $\beta_{2}$-AR-mediated cAMP-PKA pathways to enhance DC production of IL-33, resulting in direct Th2 differentiation and possibly contributing to the stress-related progression of Th2-associated disorders (Yanagawa et al., 2011). Sympathoadrenergic modulation of the skin innate and adaptive immune response occurring after stimulation with TLR2 (but not TLR4) agonists may promote a Th1 adaptive response possibly relevant to Th1-sustained autoimmune inflammatory skin diseases (Manni and Maestroni, 2008). In agreement with these findings, the $\beta_{2}-\mathrm{AR}$ agonists salbutamol may bias DC preexposed to TLR-2 and NOD2 agonists toward increasing the Th17/Th1 cell ratio finally resulting in an IL-17 immune response, which may be relevant in defense against extracellular bacteria, in the pathogenesis of inflammatory diseases and for the antitumor response (Manni et al., 2011). Adrenaline however was also shown to lead bone marrow-derived murine DC to generate a dominant Th2/Th17 phenotype, possibly through the activation of $\beta_{2}$-AR (Kim and Jones, 2010). Nonetheless, recently it was shown that $\beta_{2}$ AR agonist-exposed mature murine DC displayed a reduced ability to cross-present protein antigens while retaining their exogenous peptide presentation capability, an effect which could be mediated through a nonclassical inhibitory $\mathrm{G}(\mathrm{G} \alpha \mathrm{i} / 0)$ protein. Inhibition of cross-presentation was neither due to reduced costimulatory molecule expression nor antigen uptake, but rather to impaired phagosomal antigen degradation. A crosstalk between the TLR4 and $\beta_{2}$-AR transduction pathways at the NF- $\kappa \mathrm{B}$ level was also described, and in vivo treatment with a $\beta_{2}$-AR agonist resulted in inhibition of antigen protein crosspresentation to CD8+ T cells, however with preservation of their exogenous major histocompatibility complex (MHC) class I peptide presentation capability (Hervé et al., 2013).

Recently, pharmacological evidence was also provided for the occurrence on murine DC of $\alpha_{2}$-AR, which may mediate enhancement of antigen capture, possibly contributing to explain immune enhancement following acute stress (Yanagawa et al., 2010). Dexmedetomidine, a highly-selective $\alpha_{2}$-AR agonist, has been recently shown to affect murine bone marrow-derived DC, delaying the intracellular proteolytic degradation of ovalbumin, decreasing the expression of the surface molecules I-A(b) and CD86, and suppressing Th-cell proliferation. Dexmedetomidine also suppressed DC migration, and vaccination of animals with dexmedetomidine-treated DC significantly suppressed the contact hypersensitivity reaction in vivo (Ueshima et al., 2013).

AR-dependent modulation of DC may be relevant also to cancer vaccine strategies. Botta and Maestroni (2008) found that $\beta_{2}$-AR antagonism along with TLR2 activation at the site of intradermal cancer vaccination may either enhance the resulting antitumor response or be tolerogenic in dependence of the maturation state of the transferred DC. Manipulation of $\beta_{2}$-AR 
expressed in the site of DC inoculation may thus profoundly influence the efficacy of the subsequent antitumor response.

\section{Natural Killer Cells}

NK cells, like other innate immune cells, were described as nonspecific in their interactions with tumors or virus-infected cells, however it is now well-defined that they express a repertoire of inhibitory receptors (some specific for MHC class I, others binding non-MHC ligands) that regulate their activation. NK cells also express activating receptors, and their complex interplay with inhibitory receptors is a matter of intense investigation. NK cells circulate through the blood, lymphatics and tissues, patrolling the body for the presence of transformed or pathogen-infected cells (Yokoyama, 2005; Lanier, 2008; Chijioke and Münz, 2013).

Human NK cells express high levels of $\beta$-AR. The highest number of $\beta$-AR was found in CD16+CD56+ NK cells, and it was even increased after physical exercise (Maisel et al., 1990). Noradrenaline and adrenaline decrease NK cell cytotoxicity through the activation of $\beta$-AR (likely $\beta_{2}-\mathrm{AR}$ ) (Whalen and Bankhurst, 1990; Takamoto et al., 1991), however adrenaline may also stimulate NK cell cytotoxicity at lower (submicromolarpicomolar) concentrations (Hellstrand et al., 1985). In vitro, $\beta_{2}-$ AR activation on NK cells reduces cell adhesion to endothelial cells (Benschop et al., 1994, 1997), and in human subjects administration of both adrenaline and noradrenaline modulates the migratory capacity of human NK cells via spleen-independent $\beta_{2}$-AR mechanism (Schedlowski et al., 1996; Benschop et al., 1997). Nonetheless, evidence for $\beta$-AR-dependent increase of NK cytotoxicity has been obtained in rats treated with amphetamine (Glac et al., 2006) and more recently it has been shown that also repeated social disruption in mice "primes" NK cells in the spleen and lung to be more proficient in their cytolytic and anti-viral/tumor effecter functions through $\beta$-AR activation (Tarr et al., 2012). Also in light of such evidence, the possibility that the previously reported $\beta$-AR- dependent decreased NK cells function may arise from methodological issues has been the subject of an interesting commentary (Ben-Eliyahu, 2012). Nonetheless, a recent in vitro study which screened 1200 in-use or previously approved drugs for their biological effect on freshly isolated human peripheral blood-derived NK cells included $\beta_{2}$ AR agonists among the confirmed inhibitors (Theorell et al., 2014) and that in general acute administration of catecholamines (mimicking a stress condition) in vivo, through the interaction with $\beta$-AR, suppress NK activity (Rosenne et al., 2014).

Human NK cells also express $\alpha$-AR. In CD16+ lymphocytes, $\beta_{2^{-}}, \alpha_{1^{-}}, \alpha_{2}-\mathrm{AR}$ (but not $\beta_{1^{-}} \mathrm{AR}$ ) were identified, and infusion of adrenaline (but not noradrenaline) significantly decreased all AR on NK cells (Jetschmann et al., 1997). Recently, rat NK cells were shown to express both $\alpha_{1}$ - and $\alpha_{2}$-AR. Activation of either subtypes of $\alpha$-AR augmented NK cytotoxicity, $\alpha_{1}$-AR possibly signaling through PLC, while $\alpha_{2}$-AR effect through PKA (Xiao et al., 2010).

Decreased NK activity induced by activation of $\beta$-AR is presently considered among the main mechanisms responsible for cancer progression associated with stressful conditions resulting in activation of the sympathetic nervous system
(Shakhar and Ben-Eliyahu, 1998; Ben-Eliyahu et al., 2000; Page and Ben-Eliyahu, 2000). Noradrenaline however may also inhibit the generation of specific antitumor cytotoxic $\mathrm{T}$ lymphocytes (Kalinichenko et al., 1999), and even chemical denervation may lead to tumor growth (Brenner et al., 1992), thus suggesting a complex role of the sympathetic nervous system in the regulation of antitumor immunity.

In animal models, activation of the sympathoadrenergic system through either stressful events or direct stimulation of $\beta$-AR usually leads to compromised resistance to tumor development and metastasis (Stefanski and Ben-Eliyahu, 1996; Shakhar and Ben-Eliyahu, 1998). In a mouse model of restraint stress, plasma adrenaline significantly rose immediately after the release from restraint, while NK cells were decreased in the lungs and blood but not in the spleen. Decreased number of NK cells in the lungs and blood was reversed by the $\beta$ AR antagonist propranolol, suggesting that acute stress reduces the number of intraparenchymal lung NK cells via activation of $\beta$-AR receptors (Kanemi et al., 2005). Impairment of NK activity and reduced antitumor resistance due to stress and $\beta$-AR stimulation is affected by age (Page and Ben-Eliyahu, 2000) and by gender (Page et al., 2008). Administration of type-C CpG oligodeoxynucleotides (CpG-C ODN) was shown to improve NK activity and immunocompetence, potentially reducing metastatic dissemination after enhanced sympathetic stress responses (Goldfarb et al., 2009), and it was proposed to limit postoperative immunosuppression and metastatic progression in association with pharmacological blockade of $\beta$-AR and cyclooxygenase (COX) inhibition (Goldfarb et al., 2011). Blockade of $\beta$-AR in association with COX inhibitors have been recently proposed even in patients with hematological malignancies, based on results obtained in animals and showing that endogenous adrenaline together with prostaglandins may mediate the promoting effects of stress on leukemia progression through suppression of NK activity (Inbar et al., 2011).

Epidemiological studies support the hypothesis that exposure to $\beta_{2}$-AR antagonists may indeed reduce cancer progression and mortality, e.g., in melanoma (De Giorgi et al., 2011) and in breast cancer (Powe et al., 2010), although conflicting results have also been reported (Shah et al., 2011; Choi et al., 2014). Whether such effects are related to $\beta$-AR-induced suppression of NK antitumor activity and/or to other effects of adrenaline and noradrenaline on antitumor immunity and on tumor biology is still a matter of debate. In any case, well-designed randomized clinical trials are needed for several cancer types to establish the potential of AR manipulation as antitumor therapy.

\section{$\gamma \delta \mathrm{T}$ Lymphocytes}

Gamma delta $(\gamma \delta) \mathrm{T}$ lymphocytes are unconventional $\mathrm{T}$ cells that, like NK cells, functionally and phenotypically belong to both the innate and the adaptive immune system and represent a connection between the two. They represent about $1-10 \%$ of circulating $\mathrm{T}$ cells (and even 50\% at some mucosal sites), and are involved in the defense against infectious diseases as well as in the inhibition of tumor development and progression (Carding and Egan, 2002). Recently, one study compared lymphocytosis in response to an acute speech stress task, high 
and low intensity concentric exercise, and isoproterenol infusion at two different doses, showing that $\gamma \delta \mathrm{T}$ lymphocytes were mobilized in response to all three tasks in a dose-dependent manner, and that their mobilization was greater than that of CD8+ T lymphocytes and less than NK cells. The authors suggest that mobilization of $\gamma \delta \mathrm{T}$ lymphocytes may provide protection in the context of situations in which antigen exposure is more likely to occur (Anane et al., 2009). Another study in healthy subjects using infusion of adrenaline at physiological concentrations confirmed such results, showing that $\gamma \delta \mathrm{T}$ cells, together with CCR7-CD45RA+CD8+ effector T cells, CD3+CD56+ NKT-like cells, CD16+CD56dim cytotoxic NK cells, and CD14dimCD16+ proinflammatory monocytes, show a rapid and transient increase after adrenaline. The proposed mechanism is adrenaline-induced attenuation of cell attachment to endothelium and subsequent demargination and release into the circulation to provide immediate protection from invading pathogens (Dimitrov et al., 2010).

\section{Microglia}

The first definition of the role of microglia in CNS was provided by Pio del Rio-Hortega in 1932 who in the work entitled "Cytology and cellular pathology of the nervous system" described the role and effects of these cell population into the brain (Del Rio-Hortega, 1932). In the CNS, microglia are resident mononuclear phagocytes involved mainly in immune responses and inflammatory diseases, which originate during embryogenesis from the yolk sac and enter the CNS quite early in the life of embryos. In a more recent paper, the complex physiology of these cells was widely clarified (Kettenmann et al., 2011) and in this review we can find informations about the presence of A-DR and several other receptors. Microglial cells play an important role in managing neuronal cell death, neurogenesis, and synaptic interactions, and they contribute to T-cell activation within the CNS (Katsumoto et al., 2014).

Adrenergic pathways have never been investigated in human microglia, therefore available evidence so far regards murine models. In murine microglia, by means of microarray and immunohistochemistry, $\beta_{2}-\mathrm{AR}$ and possibly $\beta_{1}$-AR and $\alpha_{2 \mathrm{~A}}-\mathrm{AR}$ have been identified (Hertz et al., 2010). $\beta$-AR activation increases the production of IL- $\beta$, TNF- $\alpha$, and IL-6 through cAMP and cAMP-dependent protein kinase (Tomozawa et al., 1995) as well as ERK1/2 and P38 MAPK (Wang et al., 2010). Nonetheless, noradrenaline acting on $\beta$-AR may also induce IL-1ra and IL-1 type II receptor expression in enriched cultures of murine microglia, thus protecting cortical neurons against IL-1 $\beta$-induced neurotoxicity (McNamee et al., 2010), and exposure to both $\beta_{1}$ - and $\beta_{2}$-AR agonists decreased TNF- $\alpha$, IL- 6 and monocyte chemoattractant protein-1 production, prevented microglia activation, reduced inflammation and exerted neuroprotective effects in LPStreated murine hippocampal slices (Markus et al., 2010). Both noradrenaline and isoprenaline promote amyloid $\beta$ peptide uptake and degradation by murine microglial cells through activation of $\beta_{2}-\mathrm{AR}$, thus providing a potential link between central noradrenergic neurotransmission and neuroinflammatory mechanisms in Alzheimer's disease (Kong et al., 2010). Preliminary evidence obtained in human microglialike (THP-1) cells seems to confirm the antiinflammatory and neuroprotective role of noradrenaline in Alzheimer's disease pathology. In these cells, noradrenaline suppressed $A \beta 1-42-$ mediated cytotoxicity and $\mathrm{MCP}-1$ secretion, while enhancing $\mathrm{A} \beta$ mediated IL- $1 \beta$ secretion through action at $\beta_{2}-\mathrm{AR}$, and activation of cAMP/PKA pathway and CREB (Yang et al., 2012). As regards $\alpha$-AR, no information exists with the exception of a recent study in a rat model of monoarthritis, where it was shown that spinal glia, as well as dorsal root ganglion primary afferent neurons, express $\alpha_{2}$ - AR and that the $\alpha_{2}$-AR agonist dexmedetomidine exerted analgesic effects involving the blockade of spinal glial activation (Xu et al., 2010).

\section{Astrocytes}

The term astroctyes includes at least two main categories of cells that can be divided according to their morphology and anatomical localization: protoplasmic cells and fibrous cells (Sofroniew and Vinters, 2010). The first type are present in the gray matter and were the first type of astrocytes identified by means of silver impregnation. Fibrous astrocytes are localized into the white matter and are quite different in the morphology. At present we know that astrocytes are the most abundant and heterogeneous neuroglial cells, their functions including participating in the formation of the blood-brain barrier and regulation of blood flow (by releasing several molecular mediators such as prostaglandins, nitric oxide, and arachidonic acid), maintaining the ion, $\mathrm{pH}$, and transmitter homeostasis of the synaptic interstitial fluid, sensing transmitter release at the synaptic cleft and possibly releasing gliotransmitters, defending the CNS from all types of insults and disease through reactive gliosis. Astrocytes may also contribute to neuroinflammation upon severe challenges by releasing pro-inflammatory molecules (e.g., TNF- $\alpha$, IL-1, IL-6) and possibly by contributing to antigen presentation under autoimmune response, although this latter function needs further investigation (Kimelberg and Nedergaard, 2010; Endo et al., 2015).

The main AR expressed by human astrocytes is the $\beta_{2}-\mathrm{AR}$, which regulates glycogen metabolism, immune responses, release of neurotrophic factors, as well as astrogliosis in response to neuronal injury. Astrocytic $\beta_{2}-\mathrm{AR}$ are potent regulators of astrocytic TNF- $\alpha$-activated genes, including IL-6, CXCL2, CXCL3, VCAM1, and ICAM1 expression, and in rats co-administration of the $\beta_{2}$-AR agonist clenbuterol and TNF- $\alpha$ skewed the T cell population toward a double negative phenotype and induced a shift in the myeloid brain cell population toward a neutrophilic predominance, suggesting that astrocytic $\beta_{2}-\mathrm{AR}$ and their downstream signaling pathway may serve as potential targets to modulate neuroinflammatory responses (Laureys et al., 2014). Nonetheless, $\beta$-AR stimulation together with TNF-receptor triggering may also induce synergistic IL-6 expression in astrocytes, which may contribute to neurodegeneration and glioma development (Spooren et al., 2011). Downregulation of the astrocytic $\beta_{2}$-AR-pathway has been proposed to contribute to several neurological conditions such as multiple sclerosis, Alzheimer's disease, human immunodeficiency virus encephalitis, stroke, and hepatic 
encephalopathy (Laureys et al., 2010). In particular, regarding multiple sclerosis, available evidence indicates that $\beta_{2}$-AR are decreased in astrocytes of patients, both in normal-appearing white matter as well as in chronic active and inactive plaques (De Keyser et al., 1999; Zeinstra et al., 2000), and it has been proposed that in this disease astrocytes may serve as primary (facultative) antigen-presenting cells due to a failure of $\beta_{2}$-AR-mediated suppression of MHC II molecules (De Keyser et al., 2003). Astrocyte $\beta_{2}$-AR dysregulation however may contribute to pathogenesis and progression of multiple sclerosis also through deficient inhibition of nitric oxide and proinflammatory cytokine production and glutamate uptake, as well as through deficient glycogenolysis and production of trophic factors (De Keyser et al., 2004), and reduced perfusion of normal-appearing white matter (De Keyser et al., 2008). Astrocytes as therapeutic targets in multiple sclerosis were challenged in a proof of concept clinical study by use of fluoxetine, which activates PKA in astrocytes. PKA is physiologically activated by $\beta_{2}$-AR-mediated cAMP increase and in turn suppresses coactivator class II transactivator, which regulates MHC class II molecule transcription (De Keyser et al., 2010). Direct activation of PKA could in principle bypass the functional deficiency of astrocytes, however preliminary results need to be confirmed and extended in larger, randomized studies.

No information exists regarding $\alpha$-AR, with the exception of a study showing the occurrence of $\alpha_{1}$-AR in astrocytes from human optic nerves (Mantyh et al., 1995). Interestingly, the human U373 MG astrocytoma cell line express $\alpha_{1 \mathrm{~B}}$-AR coupled to phosphoinositide hydrolysis and calcium mobilization, which mediate a mitogenic response to $\alpha_{1}$-AR-agonists (Arias-Montaño et al., 1999).

\section{Conclusions and Perspectives}

Although adrenergic pathways represent the main channel of communication between the nervous system and the immune system, their role has received more attention as regards modulation of adaptive immunity (Elenkov et al., 2000; Cosentino and Marino, 2013; Marino and Cosentino, 2013), in comparison to innate immunity.

Consistent evidence however indicates that adrenergic mechanisms play a significant role even in immune cells. In particular, in human neutrophils migration, $\mathrm{CD} 11 \mathrm{~b} / \mathrm{CD} 18$ expression, and oxidative metabolism are inhibited possibly through $\beta$-AR, although a contribution by $\alpha_{1}$ - and $\alpha_{2}$-AR cannot be discarded. Inhibitory $\beta$-AR may occur also on NK cells, which also express $\alpha$-AR with undefined functional role. Monocytes express $\beta$-AR which are usually antiinflammatory, even if in certain conditions proinflammatory responses may arise. Murine $\mathrm{DC}$ express $\beta$-AR which modulate DC-T cells interactions, while in human DC $\beta_{2}$-AR may affect Th1/2 differentiation of $\mathrm{CD} 4+\mathrm{T}$ cells. $\beta_{2}-\mathrm{AR}$ dysregulation in microglia and astrocytes may contribute to neuroinflammation in autoimmune and neurodegenerative disease. As a whole, the main AR expressed on innate immune cells are $\beta$ (possibly $\beta_{2}$ )-AR, although $\alpha$-AR may occur on selected cell types and under specific conditions. Further studies however are needed to define the functional significance of $\alpha$-AR-mediated influence on the innate immune response.

On these basis, evaluation of $\beta$-AR agonists as potential antiinflammatory drugs is strongly warranted. Agonists of $\beta_{2}-\mathrm{AR}$ are currently used as bronchodilating agents in asthma, however the relative contribution of any eventual immunomodulating activity of these drugs to their overall therapeutic effects remains to be established. In addition, their usefulness in different inflammatory conditions such as atherosclerosis, where neutrophils are emerging key players (Marino et al., 2015), should be carefully considered. On the other side, $\beta$-AR antagonists might enhance the innate immune response, and therefore their usefulness could be evaluated e.g., in the potentiation of antitumor immunity. The possible immune effects of $\alpha$-AR ligands require additional investigation.

Issues awaiting clarification include AR expression and function in the various innate immune cells subtypes, as well as their effects on the humoral innate immune system (complement, antibacterial peptides). In particular, no information is yet available on innate immune cells which have been recently discovered and characterized, such as ILC (Spits et al., 2013) and myeloid-derived suppressor cells (MDSC) (Gantt et al., 2014).

Circumstantial evidence also suggests the opportunity to apply a pharmacogenetic approach to better understand adrenergic modulation of the immune response and in particular of innate immunity. For instance, individuals who were homozygous for $\beta_{2}$-AR Arg16 had higher levels of specific IgE to Ascaris lumbricoides, higher A. lumbricoides egg counts, and larger wheal sizes following skin-prick testing with $A$. lumbricoides allergen (Ramsay et al., 1999), and inhibition of IgEmediated release of histamine from human lung mast cells is more resistant to desensitization when the $\beta_{2}$-AR bears mutant (gly16 and glu27) forms compared to wild-type ( $\arg 16$ and gln27) forms (Chong et al., 2000).

Nonetheless, the present knowledge about the adrenergic modulation of innate immunity already supports relevant therapeutic applications, such as the use of $\alpha_{2}$-AR antagonists in acute lung injury (Flierl et al., 2007, 2009), as well as of $\beta$ AR antagonists to reduce the risk of opportunistic infections in severely burned patients (Kobayashi et al., 2011). Moreover, as adrenergic pathways also provide a link between stressful events and chronic inflammatory disease such as atherosclerosis (Heidt et al., 2014), investigating neuroimmune adrenergic mechanisms will likely provide several opportunities to repurpose the wide array of sympathoadrenergic agents currently used in medical therapy for various non-immune indications for novel and previously unanticipated indications. 


\section{References}

Ahlquist, R. P. (1948). A study of the adrenotropic receptors. Am. J. Physiol. 153, 586-600.

Anane, L. H., Edwards, K. M., Burns, V. E., Drayson, M. T., and Bosch, J. A. (2009). Mobilization of gammadelta T lymphocytes in response to psychological stress, exercise, and beta-agonist infusion. Brain Behav. Immun. 23, 823-829. doi: 10.1016/j.bbi.2009.03.003

Arias-Montaño, J. A., Berger, V. A., Soria-Jasso, L. E., and Young, J. M. (1999). Characterisation of alphalB-adrenoceptors linked to inositol phosphate formation and calcium mobilisation in human astrocytoma U373 MG cells. Naunyn Schmiedebergs Arch. Pharmacol. 360, 533-539.

Armaiz-Pena, G. N., Gonzalez-Villasana, V., Nagaraja, A. S., Rodriguez-Aguayo, C., Sadaoui, N. C., Stone, R. L., et al. (2015). Adrenergic regulation of monocyte chemotactic protein 1 leads to enhanced macrophage recruitment and ovarian carcinoma growth. Oncotarget 6, 4266-4273.

Auffray, C., Sieweke, M. H., and Geissmann, F. (2009). Blood monocytes: development, heterogeneity, and relationship with dendritic cells. Annu. Rev. Immunol. 27, 669-692. doi: 10.1146/annurev.immunol.021908.132557

Baker, A. J., and Fuller, R. W. (1995). Loss of response to beta-adrenoceptor agonists during the maturation of human monocytes to macrophages in vitro. J. Leukoc. Biol. 57, 395-400.

Balsa, M. D., Gómez, N., and Unzeta, M. (1989). Characterization of monoamine oxidase activity present in human granulocytes and lymphocytes. Biochim. Biophys. Acta 992, 140-144. doi: 10.1016/0304-4165(89)90002-0

Barnes, P. J. (1993). Beta-adrenoceptors on smooth muscle, nerves and inflammatory cells. Life Sci. 52, 2101-2109. doi: 10.1016/0024-3205(93)90725-I

Ben-Eliyahu, S. (2012). Can we really know if a stressor increases or decreases natural killer cell activity? Brain Behav. Immun. 26, 1224-1225. doi: 10.1016/j.bbi.2012.08.004

Ben-Eliyahu, S., Shakhar, G., Page, G. G., Stefanski, V., and Shakhar, K. (2000). Suppression of NK cell activity and of resistance to metastasis by stress: a role for adrenal catecholamines and beta-adrenoceptors. Neuroimmunomodulation 8, 154-164. doi: 10.1159/000054276

Benschop, R. J., Nijkamp, F. P., Ballieux, R. E., and Heijnen, C. J. (1994). The effects of beta-adrenoceptor stimulation on adhesion of human natural killer cells to cultured endothelium. Br. J. Pharmacol. 113, 1311-1316.

Benschop, R. J., Schedlowski, M., Wienecke, H., Jacobs, R., and Schmidt, R. E. (1997). Adrenergic control of natural killer cell circulation and adhesion. Brain Behav. Immun. 11, 321-332. doi: 10.1006/brbi.1997.0499

Biswas, S. K., and Mantovani, A. (2010). Macrophage plasticity and interaction with lymphocyte subsets: cancer as a paradigm. Nat. Immunol. 11, 889-896. doi: $10.1038 /$ ni.1937

Boman, H. G. (2003). Antimicrobial peptides: basic facts and emerging concepts. J. Intern. Med. 254, 197-215. doi: 10.1046/j.1365-2796.2003.01228.x

Borda, E. S., Tenenbaum, A., Sales, M. E., Rumi, L., and Sterin-Borda, L. (1998). Role of arachidonic acid metabolites in the action of a beta adrenergic agonist on human monocyte phagocytosis. Prostaglandins Leukot. Essent. Fatty Acids 58, 85-90. doi: 10.1016/S0952-3278(98)90145-4

Botta, F., and Maestroni, G. J. (2008). Adrenergic modulation of dendritic cell cancer vaccine in a mouse model: role of dendritic cell maturation. J. Immunother. 31, 263-270. doi: 10.1097/CJI.0b013e318160995e

Boutajangout, A., and Wisniewski, T. (2013). The innate immune system in Alzheimer's disease. Int. J. Cell Biol. 2013:576383. doi: 10.1155/2013/576383

Bowden Sulakvelidze, I., and McDonald, D. M. (1994). Inhibition of neutrophil and eosinophil adhesion to venules of rat trachea by beta 2 -adrenergic agonist formoterol. J. Appl. Physiol. 77, 397-405.

Brenner, G. J., Felten, S. Y., Felten, D. L., and Moynihan, J. A. (1992). Sympathetic nervous system modulation of tumor metastases and host defense mechanisms. J. Neuroimmunol. 37, 191-201.

Brunskole Hummel, I., Reinartz, M. T., Kälble, S., Burhenne, H., Schwede, F., Seifert, R. et al. (2013). Dissociations in the effects of $\beta 2$-adrenergic receptor agonists on cAMP formation and superoxide production in human neutrophils: support for the concept of functional selectivity. PLoS ONE 8:e64556. doi: 10.1371/journal.pone.0064556

Bylund, D. B., Eikenberg, D. C., Hieble, J. P., Langer, S. Z., Lefkowitz, R. J., Minneman, K. P., et al. (1994). International union of pharmacology nomenclature of adrenoceptors. Pharmacol. Rev. 46, 121-136.
Carding, S. R., and Egan, P. J. (2002). Gammadelta T cells: functional plasticity and heterogeneity. Nat. Rev. Immunol. 2, 336-345. doi: 10.1038/nri797

Chaitidis, P., Billett, E. E., O’Donnell, V. B., Fajardo, A. B., Fitzgerald, J., Kuban, R. J., et al. (2004). Th2 response of human peripheral monocytes involves isoformspecific induction of monoamine oxidase-A. J. Immunol. 173, 4821-4827. doi: 10.4049/jimmunol.173.8.4821

Chaitidis, P., O’Donnell, V., Kuban, R. J., Bermudez-Fajardo, A., Ungethuem, U., and Kühn, H. (2005). Gene expression alterations of human peripheral blood monocytes induced by medium-term treatment with the TH2-cytokines interleukin-4 and -13. Cytokine 30, 366-377. doi: 10.1016/j.cyto.2005.02.004

Chávez-Sánchez, L., Espinosa-Luna, J. E., Chávez-Rueda, K., Legorreta-Haquet, M. V., Montoya-Díaz, E., and Blanco-Favela, F. (2014). Innate immune system cells in atherosclerosis. Arch. Med. Res. 45, 1-14. doi: 10.1016/j.arcmed.2013.11.007

Chijioke, O., and Münz, C. (2013). Dendritic cell derived cytokines in human natural killer cell differentiation and activation. Front. Immunol. 4:365. doi: 10.3389/fimmu.2013.00365

Choi, C. H., Song, T., Kim, T. H., Choi, J. K., Park, J. Y., Kim, B. G., et al. (2014). Meta-analysis of the effects of beta blocker on survival time in cancer patients. J. Cancer Res. Clin. Oncol. 140, 1179-1188. doi: 10.1007/s00432-014-1658-7

Chong, L. K., Chess-Williams, R., and Peachell, P. T. (2002). Pharmacological characterisation of the beta-adrenoceptor expressed by human lung mast cells. Eur. J. Pharmacol. 437, 1-7. doi: 10.1016/S0014-2999(02)01263-3

Chong, L. K., Chowdry, J., Ghahramani, P., and Peachell, P. T. (2000). Influence of genetic polymorphisms in the beta2-adrenoceptor on desensitization in human lung mast cells. Pharmacogenetics 10, 153-162. doi: 10.1097/00008571200003000-00007

Chong, L. K., Morice, A. H., Yeo, W. W., Schleimer, R. P., and Peachell, P. T. (1995). Functional desensitization of beta agonist responses in human lung mast cells. Am. J. Respir. Cell Mol. Biol. 13, 540-546. doi: 10.1165/ajrcmb.13.5.7576689

Chou, R. C., Dong, X. L., Noble, B. K., Knight, P. R., and Spengler, R. N. (1998). Adrenergic regulation of macrophage-derived tumor necrosis factoralpha generation during a chronic polyarthritis pain model. J. Neuroimmunol. 82, 140-148. doi: 10.1016/S0165-5728(97)00196-3

Cnop, M., Welsh, N., Jonas, J. C., Jörns, A., Lenzen, S., and Eizirik, D. L. (2005). Mechanisms of pancreatic beta-cell death in Type 1 and Type 2 diabetes: many differences, few similarities. Diabetes 54(Suppl. 2), S97-S107. doi: 10.2337/diabetes.54.suppl_2.S97

Corradi, L., Negri, F., Parini, A., Partesana, N., and Finardi, G. (1981). Decreased beta-adrenoceptors in polymorphonucleates in essential hypertension. Boll. Soc. Ital. Biol. Sper. 57, 1766-1770.

Cosentino, M., and Marino, F. (2013). Adrenergic and dopaminergic modulation of immunity in multiple sclerosis: teaching old drugs new tricks? J. Neuroimmune Pharmacol. 8, 163-179. doi: 10.1007/s11481-012-9410-z

Cosentino, M., Marino, F., Bombelli, R., Ferrari, M., Lecchini, S., and Frigo, G. (1999). Endogenous catecholamine synthesis, metabolism, storage and uptake in human neutrophils. Life Sci. 64, 975-981. doi: 10.1016/S00243205(99)00023-5

Cotter, T. G., and O'Malley, K. (1983). Decreased neutrophil cyclic AMP response to isoprenaline stimulation in the elderly. Clin Sci. (Lond.) 65, 155-157.

Courties, G., Moskowitz, M. A., and Nahrendorf, M. (2014). The innate immune system after ischemic injury: lessons to be learned from the heart and brain. JAMA Neurol. 71, 233-236. doi: 10.1001/jamaneurol.2013.5026

Cruse, G., Yang, W., Duffy, S. M., Chachi, L., Leyland, M., Amrani, Y., et al. (2010). Counterregulation of beta(2)-adrenoceptor function in human mast cells by stem cell factor. J. Allergy Clin. Immunol. 125, 257-63.e1-5. doi: 10.1016/j.jaci.2009.08.020

da Silva, E. Z., Jamur, M. C., and Oliver, C. (2014). Mast cell function: a new vision of an old cell. J. Histochem. Cytochem. 62, 698-738. doi: $10.1369 / 0022155414545334$

De Giorgi, V., Grazzini, M., Gandini, S., Benemei, S., Lotti, T., Marchionni, N., et al. (2011). Treatment with $\beta$-blockers and reduced disease progression in patients with thick melanoma. Arch. Intern. Med. 171, 779-781. doi: 10.1001/archinternmed.2011.131

De Keyser, J., Laureys, G., Demol, F., Wilczak, N., Mostert, J., and Clinckers, R. (2010). Astrocytes as potential targets to suppress inflammatory demyelinating lesions in multiple sclerosis. Neurochem. Int. 57, 446-450. doi: 10.1016/j.neuint.2010.02.012 
De Keyser, J., Steen, C., Mostert, J. P., and Koch, M. W. (2008). Hypoperfusion of the cerebral white matter in multiple sclerosis: possible mechanisms and pathophysiological significance. J. Cereb. Blood Flow Metab. 28, 1645-1651. doi: $10.1038 /$ jcbfm.2008.72

De Keyser, J., Wilczak, N., Leta, R., and Streetland, C. (1999). Astrocytes in multiple sclerosis lack beta-2 adrenergic receptors. Neurology 53, 1628-1633. doi: 10.1212/WNL.53.8.1628

De Keyser, J., Zeinstra, E., and Frohman, E. (2003). Are astrocytes central players in the pathophysiology of multiple sclerosis? Arch. Neurol. 60, 132-136. doi: 10.1001/archneur.60.1.132

De Keyser, J., Zeinstra, E., and Wilczak, N. (2004). Astrocytic beta2adrenergic receptors and multiple sclerosis. Neurobiol. Dis. 15, 331-339. doi: 10.1016/j.nbd.2003.10.012

De Kleer, I., Willems, F., Lambrecht, B., and Goriely, S. (2014). Ontogeny of myeloid cells. Front. Immunol. 5:423. doi: 10.3389/fimmu.2014.00423

Del Rio-Hortega, P. (1932). "Microglia," in Cytology and Cellular Pathology of the Nervous System, ed W. Penfield (New York, NY: Hoeber), 482-534.

Dimitrov, S., Lange, T., and Born, J. (2010). Selective mobilization of cytotoxic leukocytes by epinephrine. J. Immunol. 184, 503-511. doi: 10.4049/jimmunol.0902189

Du, Y., Yan, L., Du, H., Wang, L., Ding, F., Quan, L., et al. (2012). $\beta 1$-adrenergic receptor autoantibodies from heart failure patients enhanced TNF- $\alpha$ secretion in RAW264.7 macrophages in a largely PKAdependent fashion. J. Cell. Biochem. 113, 3218-3228. doi: 10.1002/jcb. 24198

Elenkov, I. J., Wilder, R. L., Chrousos, G. P., and Vizi, E. S. (2000). The sympathetic nerve-an integrative interface between two supersystems: the brain and the immune system. Pharmacol. Rev. 52, 595-638.

Endo, F., Komine, O., Fujimori-Tonou, N., Katsuno, M., Jin, S., Watanabe, S., et al. (2015). Astrocyte-derived TGF- $\beta 1$ accelerates disease progression in ALS mice by interfering with the neuroprotective functions of microglia and T cells. Cell Rep. 11, 592-604. doi: 10.1016/j.celrep.2015.03.053

Ezeamuzie, C. I., Shihab, P. K., and Al-Radwan, R. (2011). Loss of surface beta2 adrenoceptors accounts for the insensitivity of cultured human monocytes to beta-2 adrenoceptor agonists. Int. Immunopharmacol. 11, 1189-1194. doi: 10.1016/j.intimp.2011.03.017

Farrar, C. A., Kupiec-Weglinski, J. W., and Sacks, S. H. (2013). The innate immune system and transplantation. Cold Spring Harb. Perspect. Med. 3:a015479. doi: 10.1101/cshperspect.a015479

Feldman, R. S., Meyer, J. S., and Quenzer, L. F. (eds.). (1997). “Catecholamines," in Principles of Neuropsychopharmacology (Sunderland, MA: Sinauer Associates Inc), 277-344.

Flierl, M. A., Rittirsch, D., Chen, A. J., Nadeau, B. A., Day, D. E., Sarma, J. V., et al. (2008b). The complement anaphylatoxin C5a induces apoptosis in adrenomedullary cells during experimental sepsis. PLoS ONE 3:e2560. doi: 10.1371/journal.pone.0002560

Flierl, M. A., Rittirsch, D., Nadeau, B. A., Chen, A. J., Sarma, J. V., Zetoune, F. S., et al. (2007). Phagocyte-derived catecholamines enhance acute inflammatory injury. Nature 449, 721-725. doi: 10.1038/nature06185

Flierl, M. A., Rittirsch, D., Nadeau, B. A., Sarma, J. V., Day, D. E., Lentsch, A. B., et al. (2009). Upregulation of phagocyte-derived catecholamines augments the acute inflammatory response. PLOS ONE 4:e4414. doi: 10.1371/journal.pone.0004414

Flierl, M. A., Rittirsch, D., Sarma, J. V., Huber-Lang, M., and Ward, P. A. (2008a). Adrenergic regulation of complement-induced acute lung injury. Adv. Exp. Med. Biol. 632, 93-103. doi: 10.1007/978-0-387-78952-1_8

Fragala, M. S., Kraemer, W. J., Mastro, A. M., Denegar, C. R., Volek, J. S., Häkkinen, K., et al. (2011). Leukocyte $\beta 2$-adrenergic receptor expression in response to resistance exercise. Med. Sci. Sports Exerc. 43, 1422-1432. doi: 10.1249/MSS.0b013e31820b88bc

Gantt, S., Gervassi, A., Jaspan, H., and Horton, H. (2014). The role of myeloidderived suppressor cells in immune ontogeny. Front. Immunol. 5:387. doi: 10.3389/fimmu.2014.00387

Gauthier, C., Tavernier, G., Charpentier, F., Langin, D., and Lemarec, H. (1996). Functional beta (3)-adrenoceptor in the human heart. J. Clin. Invest. 98, 556-562. doi: 10.1172/JCI118823

Gebhardt, T., Gerhard, R., Bedoui, S., Erpenbeck, V. J., Hoffmann, M. W., Manns, M. P., et al. (2005). beta2-Adrenoceptor-mediated suppression of human intestinal mast cell functions is caused by disruption of filamentous actin dynamics. Eur. J. Immunol. 35, 1124-1132. doi: 10.1002/eji.200425869

Geissmann, F., Manz, M. G., Jung, S., Sieweke, M. H., Merad, M., and Ley, K. (2010). Development of monocytes, macrophages, and dendritic cells. Science 327, 656-661. doi: 10.1126/science.1178331

Glac, W., Borman, A., Badtke, P., Stojek, W., Orlikowska, A., and Tokarski, J. (2006). Amphetamine enhances natural killer cytotoxic activity via betaadrenergic mechanism. J. Physiol. Pharmacol. 11, 125-132.

Goldfarb, Y., Benish, M., Rosenne, E., Melamed, R., Levi, B., Glasner, A., et al. (2009). CpG-C oligodeoxynucleotides limit the deleterious effects of betaadrenoceptor stimulation on NK cytotoxicity and metastatic dissemination. J. Immunother. 32, 280-291. doi: 10.1097/CJI.0b013e31819a2982

Goldfarb, Y., Sorski, L., Benish, M., Levi, B., Melamed, R., and Ben-Eliyahu, S. (2011). Improving postoperative immune status and resistance to cancer metastasis: a combined perioperative approach of immunostimulation and prevention of excessive surgical stress responses. Ann. Surg. 253, 798-810. doi: 10.1097/SLA.0b013e318211d7b5

Goyarts, E., Matsui, M., Mammone, T., Bender, A. M., Wagner, J. A., Maes, D., et al. (2008). Norepinephrine modulates human dendritic cell activation by altering cytokine release. Exp. Dermatol. 17, 188-196. doi: 10.1111/j.16000625.2007.00677.x

Grisanti, L. A., Evanson, J., Marchus, E., Jorissen, H., Woster, A. P., DeKrey, W., et al. (2010). Pro-inflammatory responses in human monocytes are beta1adrenergic receptor subtype dependent. Mol. Immunol. 47, 1244-1254. doi: 10.1016/j.molimm.2009.12.013

Grisanti, L. A., Woster, A. P., Dahlman, J., Sauter, E. R., Combs, C. K., and Porter, J. E. (2011). \{alpha\}1-adrenergic receptors positively regulate toll-like receptor cytokine production from human monocytes and macrophages. J. Pharmacol. Exp. Ther. 338, 648-657. doi: 10.1124/jpet.110.178012

Gross, C. A., Bowler, R. P., Green, R. M., Weinberger, A. R., Schnell, C., and Chu, H. W. (2010). Beta2-agonists promote host defense against bacterial infection in primary human bronchial epithelial cells. BMC Pulm. Med. 10:30. doi: 10.1186/1471-2466-10-30

Guimarães, S., and Moura, D. (2001). Vascular adrenoceptors: an update. Pharmacol. Rev. 53, 319-356.

Guirao, X., Kumar, A., Katz, J., Smith, M., Lin, E., Keogh, C., et al. (1997). Catecholamines increase monocyte TNF receptors and inhibit TNF through beta 2-adrenoreceptor activation. Am. J. Physiol. 273, E1203-E1208.

Gurguis, G. N., Andrews, R., Antai-Otong, D., Vo, S. P., Blakeley, J. E., Orsulak, P. J., et al. (1999). Neutrophil beta2-adrenergic receptor coupling efficiency to Gs protein in subjects with post-traumatic stress disorder and normal controls. Psychopharmacology (Berl.) 143, 131-140. doi: 10.1007/s002130050928

Harms, H. H., Zaagsma, J., and Van der Wal, B. (1974). $\beta$-Adrenoceptor studies. III. On the $\beta$-adrenoceptors in rat adipose tissue. Eur. J. Pharmacol. 25, 87-91. doi: 10.1016/0014-2999(74)90098-3

Heidt, T., Sager, H. B., Courties, G., Dutta, P., Iwamoto, Y., Zaltsman, A., et al. (2014). Chronic variable stress activates hematopoietic stem cells. Nat. Med. 20, 754-758. doi: 10.1038/nm.3589

Heijnen, C. J., Rouppe van der Voort, C., van de Pol, M., and Kavelaars, A. (2002). Cytokines regulate alpha(1)-adrenergic receptor mRNA expression in human monocytic cells and endothelial cells. J. Neuroimmunol. 125, 66-72. doi: 10.1016/S0165-5728(02)00034-6

Hellstrand, K., Hermodsson, S., and Strannegård, O. (1985). Evidence for a betaadrenoceptor-mediated regulation of human natural killer cells. J. Immunol. 134, 4095-4099.

Hertz, L., Lovatt, D., Goldman, S. A., and Nedergaard, M. (2010). Adrenoceptors in brain: cellular gene expression and effects on astrocytic metabolism and $[\mathrm{Ca}(2+)]$ i. Neurochem. Int. 57, 411-420. doi: 10.1016/j.neuint.2010.03.019

Hervé, J., Dubreil, L., Tardif, V., Terme, M., Pogu, S., Anegon, I., et al. (2013). $\beta 2$ Adrenoreceptor agonist inhibits antigen cross-presentation by dendritic cells. J. Immunol. 190, 3163-3171. doi: 10.4049/jimmunol.1201391

Humphreys, R. J., and Raab, W. (1950). Response of circulating eosinophils to norepinephrine, epinephrine and emotional stress in humans. Proc. Soc. Exp. Biol. Med. 74, 302-303. doi: 10.3181/00379727-74-17884

Inbar, S., Neeman, E., Avraham, R., Benish, M., Rosenne, E., and Ben-Eliyahu, S. (2011). Do stress responses promote leukemia progression? An animal study suggesting a role for epinephrine and prostaglandin-E2 through reduced NK activity. PLoS ONE 6:e19246. doi: 10.1371/journal.pone.0019246 
Izeboud, C. A., Mocking, J. A., Monshouwer, M., van Miert, A. S., and Witkamp, R. F. (1999). Participation of beta-adrenergic receptors on macrophages in modulation of LPS-induced cytokine release. J. Recept. Signal Transduct. Res. 19, 191-202.

Jetschmann, J. U., Benschop, R. J., Jacobs, R., Kemper, A., Oberbeck, R., Schmidt, R. E., et al. (1997). Expression and in-vivo modulation of alpha- and betaadrenoceptors on human natural killer (CD16+) cells. J. Neuroimmunol. 74, 159-164. doi: 10.1016/S0165-5728(96)00221-4

Jones, K. A., and Thomsen, C. (2013). The role of the innate immune system in psychiatric disorders. Mol. Cell. Neurosci. 53, 52-62. doi: 10.1016/j.mcn.2012.10.002

Kalinichenko, V. V., Mokyr, M. B., Graf, L. H. Jr., Cohen, R. L., and Chambers, D. A. (1999). Norepinephrine-mediated inhibition of antitumor cytotoxic T lymphocyte generation involves a beta-adrenergic receptor mechanism and decreased TNF-alpha gene expression. J. Immunol. 163, 2492-2499.

Kanemi, O., Zhang, X., Sakamoto, Y., Ebina, M., and Nagatomi, R. (2005). Acute stress reduces intraparenchymal lung natural killer cells via betaadrenergic stimulation. Clin. Exp. Immunol. 139, 25-34. doi: 10.1111/j.13652249.2005.02672.x

Karasuyama, H., and Yamanishi, Y. (2014). Basophils have emerged as a key player in immunity. Curr. Opin. Immunol. 31C, 1-7. doi: 10.1016/j.coi.2014.07.004

Katsumoto, A., Lu, H., Miranda, A. S., and Ransohoff, R. M. (2014). Ontogeny and Functions of Central Nervous System Macrophages. J. Immunol. 193, 2615-2621. doi: 10.4049/jimmunol.1400716

Kavelaars, A., van de Pol, M., Zijlstra, J., and Heijnen, C. J. (1997). Beta 2adrenergic activation enhances interleukin-8 production by human monocytes. J. Neuroimmunol. 77, 211-216.

Kawai, T., and Akira, S. (2010). The role of pattern-recognition receptors in innate immunity: update on Toll-like receptors. Nat. Immunol. 11, 373-384. doi: 10.1038/ni. 1863

Kay, L. J., and Peachell, P. T. (2005). Mast cell beta2-adrenoceptors. Chem. Immunol. Allergy 87, 145-153. doi: 10.1159/000087641

Kenney, M. J., and Ganta, C. K. (2014). Autonomic nervous system and immune system interactions. Compr. Physiol. 4, 1177-1200. doi: 10.1002/cphy.c130051

Kettenmann, H., Hanish, U. K., Noda, M., and Verkhratsky, A. (2011). Physiology of microglia. Physiol. Rev. 91, 461-553. doi: 10.1152/physrev.00011.2010

Kim, B. J., and Jones, H. P. (2010). Epinephrine-primed murine bone marrow-derived dendritic cells facilitate production of IL-17A and IL-4 but not IFN- $\gamma$ by CD4+ $\mathrm{T}$ cells. Brain Behav. Immun. 24, 1126-1136. doi: 10.1016/j.bbi.2010.05.003

Kimelberg, H. K., and Nedergaard, M. (2010). Functions of astrocytes and their potential as therapeutic targets. Neurotherapeutics 7, 338-353. doi: 10.1016/j.nurt.2010.07.006

Kita, H. (2013). Eosinophils: multifunctional and distinctive properties. Int. Arch. Allergy Immunol. 2, 3-9. doi: 10.1159/000350662

Kobayashi, M., Jeschke, M. G., Asai, A., Kogiso, M., Yoshida, S., Herndon, D. N., et al. (2011). Propranolol as a modulator of M2b monocytes in severely burned patients. J. Leukoc. Biol. 89, 797-803. doi: 10.1189/jlb.1010553

Koch-Weser, J. (1968). Beta adrenergic blockade and circulating eosinophils. Arch. Intern. Med. 121, 255-258. doi: 10.1001/archinte.1968.03640030047007

Kohm, A. P., and Sanders, V. M. (2001). Norepinephrine and beta 2-adrenergic receptor stimulation regulate $\mathrm{CD} 4+\mathrm{T}$ and $\mathrm{B}$ lymphocyte function in vitro and in vivo. Pharmacol. Rev. 53, 487-525.

Kong, Y., Ruan, L., Qian, L., Liu, X., and Le, Y. (2010). Norepinephrine promotes microglia to uptake and degrade amyloid beta peptide through upregulation of mouse formyl peptide receptor 2 and induction of insulin-degrading enzyme. J. Neurosci. 30, 11848-11857. doi: 10.1523/JNEUROSCI.2985-10.2010

Kozlov, L. V., and Lebedeva, T. V. (1998). Inhibition of formation of complement C5-convertase. Bioorg. Khim. 24, 350-355.

Kozlov, L. V., Lakhtin, V. M., Skorokhodova, T. G., Batalova, T. N., Shoibonov, B. B., D'Iakov, V. L., et al. (2000). Inhibition of binding of activated compliment component C4b with its target. Bioorg. Khim. 26, 817-824.

Kuebler, U., Wirtz, P. H., Sakai, M., Stemmer, A., and Ehlert, U. (2013). Acute stress reduces wound-induced activation of microbicidal potential of ex vivo isolated human monocyte-derived macrophages. PLoS ONE 8:e55875. doi: 10.1371/journal.pone.0055875

Lanier, L. L. (2008). Up on the tightrope: natural killer cell activation and inhibition. Nat. Immunol. 9, 495-502. doi: 10.1038/ni1581
Lappin, D., and Whaley, K. (1982). Adrenergic receptors on monocytes modulate complement component synthesis. Clin. Exp. Immunol. 47, 606-612.

Laureys, G., Clinckers, R., Gerlo, S., Spooren, A., Wilczak, N., Kooijman, R., et al. (2010). Astrocytic beta (2)-adrenergic receptors: from physiology to pathology. Prog. Neurobiol. 91, 189-199. doi: 10.1016/j.pneurobio.2010.01.011

Laureys, G., Gerlo, S., Spooren, A., Demol, F., De Keyser, J., and Aerts, J. L. (2014). $\beta 2$-adrenergic agonists modulate TNF- $\alpha$ induced astrocytic inflammatory gene expression and brain inflammatory cell populations. J. Neuroinflammation 11:21. doi: 10.1186/1742-2094-11-21

Le Provost, G. S., and Pullar, C. E. (2015). $\beta 2$-adrenoceptor activation modulates skin wound healing processes to reduce scarring. J. Invest. Dermatol. 135, 279-288. doi: 10.1038/jid.2014.312

Lee, M. S. (2014). Role of innate immunity in the pathogenesis of type 1 and type 2 diabetes. J. Korean Med. Sci. 29, 1038-1041. doi: 10.3346/jkms.2014.29.8.1038

Lee, S. Y., Kim, D. K., Kim, K. D., Myung, S. C., and Lee, M. Y. (2011). The relaxing effect of $\alpha$-defensin 1 on the adrenergic responses of rat bladder. Korean J. Physiol. Pharmacol. 15, 143-147. doi: 10.4196/kjpp.2011.15.3.143

Levine, A. P., and Segal, A. W. (2013). What is wrong with granulocytes in inflammatory bowel diseases? Dig. Dis. 31, 321-327. doi: 10.1159/000354686

Li, C. Y., Chou, T. C., Lee, C. H., Tsai, C. S., Loh, S. H., and Wong, C. S. (2003). Adrenaline inhibits lipopolysaccharide-induced macrophage inflammatory protein-1 alpha in human monocytes: the role of beta-adrenergic receptors. Anesth. Analg. 96, 518-523. doi: 10.1213/00000539-200302000-00040

Loegering, D. J., and Commins, L. M. (1988). Effect of beta-receptor stimulation on Kupffer cell complement receptor clearance function. Circ. Shock 25, 325-332.

Lumeng, C. N. (2013). Innate immune activation in obesity. Mol. Aspects Med. 34, 12-29. doi: 10.1016/j.mam.2012.10.002

Maestroni, G. J. (2004). Modulation of skin norepinephrine turnover by allergen sensitization: impact on contact hypersensitivity and $\mathrm{T}$ helper priming. J. Inverst. Dermatol. 122, 119-124. doi: 10.1046/j.0022-202X.2003.22132.x

Maestroni, G. J. (2005). Adrenergic modulation of dendritic cells function: relevance for the immune homeostasis. Curr. Neurovasc. Res. 2, 169-173. doi: $10.2174 / 1567202053586776$

Maestroni, G. J. (2006). Sympathetic nervous system influence on the innate immune response. Ann. N.Y. Acad. Sci. 1069, 195-207. doi: 10.1196/annals.1351.017

Maisel, A. S., Harris, T., Rearden, C. A., and Michel, M. C. (1990). Betaadrenergic receptors in lymphocyte subsets after exercise. Alterations in normal individuals and patients with congestive heart failure. Circulation 82, 2003-2010.

Mannaioni, P. F., Mastroianni, R., and Mastrangelo, D. (2010). Adrenaline inhibits the immunological activation of human basophils at pharmacological and ultra-low doses. Med. Sci. Monit. 16, BR227-BR232.

Manni, M., and Maestroni, G. J. (2008). Sympathetic nervous modulation of the skin innate and adaptive immune response to peptidoglycan but not lipopolysaccharide: involvement of beta-adrenoceptors and relevance in inflammatory diseases. Brain Behav. Immun. 22, 80-88. doi: 10.1016/j.bbi.2007.06.016

Manni, M., Granstein, R. D., and Maestroni, G. (2011). $\beta 2$-Adrenergic agonists bias TLR-2 and NOD2 activated dendritic cells towards inducing an IL-17 immune response. Cytokine 55, 380-386. doi: 10.1016/j.cyto.2011.05.013

Manning, C. D., McLaughlin, M. M., Livi, G. P., Cieslinski, L. B., Torphy, T. J., and Barnette, M. S. (1996). Prolonged beta adrenoceptor stimulation up-regulates cAMP phosphodiesterase activity in human monocytes by increasing mRNA and protein for phosphodiesterases 4A and 4B. J. Pharmacol. Exp. Ther. 276, 810-818.

Mantyh, P. W., Rogers, S. D., Allen, C. J., Catton, M. D., Ghilardi, J. R., Levin, L. A., et al. (1995). Beta 2-adrenergic receptors are expressed by glia in vivo in the normal and injured central nervous system in the rat, rabbit, and human. J. Neurosci. 15, 152-164.

Marcus, A., Gowen, B. G., Thompson, T. W., Iannello, A., Ardolino, M., Deng, W., et al. (2014). Recognition of tumors by the innate immune system and natural killer cells. Adv. Immunol. 122, 91-128. doi: 10.1016/B978-0-12800267-4.00003-1

Marino, F., and Cosentino, M. (2013). Adrenergic modulation of immune cells: an update. Amino Acids 45, 55-71. doi: 10.1007/s00726-011-1186-6

Marino, F., Tozzi, M., Schembri, L., Ferraro, S., Tarallo, A., Scanzano, A., et al. (2015). Production of IL-8, VEGF and elastase by circulating and intraplaque 
neutrophils in patients with carotid atherosclerosis. PLoS ONE 10:e124565. doi: 10.1371/journal.pone.0124565

Markus, T., Hansson, S. R., Cronberg, T., Cilio, C., Wieloch, T., and Ley, D. (2010). $\beta$-Adrenoceptor activation depresses brain inflammation and is neuroprotective in lipopolysaccharide-induced sensitization to oxygen-glucose deprivation in organotypic hippocampal slices. J. Neuroinflammation 7:94. doi: 10.1186/1742-2094-7-94

Martin-Ezquerra, G., Man, M. Q., Hupe, M., Rodriguez-Martin, M., Youm, J. K., Trullas, C., et al. (2011). Psychological stress regulates antimicrobial peptide expression by both glucocorticoid and $\beta$-adrenergic mechanisms. Eur. J. Dermatol. 2, 48-51. doi: 10.1684/ejd.2011.1273

Masini, E., Blandina, P., and Mannaioni, P. F. (1982). Mast cell receptors controlling histamine release: influences on the mode of action of drugs used in the treatment of adverse drug reactions. Klin. Wochenschr. 60, 1031-1038. doi: 10.1007/BF01716967

Mayadas, T. N., Cullere, X., and Lowell, C. A. (2014). The multifaceted functions of neutrophils. Annu. Rev. Pathol. 9, 181-218. doi: 10.1146/annurev-pathol020712-164023

Mayo, L., Quintana, F. J., and Weiner, H. L. (2012). The innate immune system in demyelinating disease. Immunol. Rev. 248, 170-187. doi: 10.1111/j.1600065X.2012.01135.x

McNamee, E. N., Ryan, K. M., Kilroy, D., and Connor, T. J. (2010). Noradrenaline induces IL-1ra and IL-1 type II receptor expression in primary glial cells and protects against IL-1beta-induced neurotoxicity. Eur. J. Pharmacol. 626, 219-228. doi: 10.1016/j.ejphar.2009.09.054

Mellman, I., and Steinman, R. M. (2001). Dendritic cells: specialized and regulated antigen processing machines. Cell 106, 255-258. doi: 10.1016/S00928674(01)00449-4

Mencia-Huerta, J. M., Paul-Eugène, N., Dugas, B., Petit-Frère, C., Gordon, J., Lagente, V., et al. (1991). Beta-2-adrenoceptor agonists up-regulate the in vitro Fc epsilon receptor II/CD23 expression on, and release from, the promonocytic cell line U937 and human blood monocytes. Int. Arch. Allergy Appl. Immunol. 94, 91-92.

Merad, M., Manz, M. G., Karsunky, H., Wagers, A., Peters, W., Charo, I., et al. (2002). Langerhans cells renew in the skin throughout life under steady-state conditions. Nat. Immunol. 3, 1135-1141. doi: 10.1038/ni852

Miadonna, A., Tedeschi, A., Leggieri, E., Parravicini, P., Lorini, M., and Zanussi, C. (1989). Clonidine inhibits IgE-mediated and IgE-independent in vitro histamine release from human basophil leukocytes. Int. J. Immunopharmacol. 11, 473-477. doi: 10.1016/0192-0561(89)90176-8

Miksa, M., Wu, R., Zhou, M., and Wang, P. (2005). Sympathetic excitotoxicity in sepsis: pro-inflammatory priming of macrophages by norepinephrine. Front. Biosci. 10, 2217-2229. doi: 10.2741/1691

Mishima, K., Otani, H., Tanabe, T., Kawasaki, H., Oshiro, A., Saito, N., et al. (2001). Molecular mechanisms for alpha2-adrenoceptor-mediated regulation of synoviocyte populations. Jpn. J. Pharmacol. 85, 214-226. doi: 10.1254/jjp.85.214

Mizuno, K., Takahashi, H. K., Iwagaki, H., Katsuno, G., Kamurul, H. A., Ohtani, S., et al. (2005). Beta2-adrenergic receptor stimulation inhibits LPS-induced IL-18 and IL-12 production in monocytes. Immunol. Lett. 101, 168-172. doi: 10.1016/j.imlet.2005.05.008

Mócsai, A. (2013). Diverse novel functions of neutrophils in immunity, inflammation, and beyond. J. Exp. Med. 210, 1283-1299. doi: 10.1084/jem. 20122220

Motojima, S., Fukuda, T., and Makino, S. (1992). Effect of eosinophil peroxidase on beta-adrenergic receptor density on guinea pig lung membrane. Biochem. Biophys. Res. Commun. 189, 1613-1619. doi: 10.1016/0006-291X(92)90261-I

Munoz, N. M., Vita, A. J., Neeley, S. P., McAllister, K., Spaethe, S. M., White, S. R., et al. (1994). Beta adrenergic modulation of formyl-methionine-leucinephenylalanine-stimulated secretion of eosinophil peroxidase and leukotriene C4. J. Pharmacol. Exp. Ther. 268, 139-143.

Musgrave, I. F., and Seifert, R. (1994). Human neutrophils and HL-60 cells do not possess alpha 2-adrenoceptors. Biochem Pharmacol. 47, 233-239. doi: 10.1016/0006-2952(94)90011-6

Nguyen, K. D., Qiu, Y., Cui, X., Goh, Y. P., Mwangi, J., David, T., et al. (2011). Alternatively activated macrophages produce catecholamines to sustain adaptive thermogenesis. Nature 480, 104-108. doi: 10.1038/nature10653
Nielson, C. P. (1987). Beta-adrenergic modulation of the polymorphonuclear leukocyte respiratory burst is dependent upon the mechanism of cell activation. J. Immunol. 139, 2392-2397.

Nijhuis, L. E., Olivier, B. J., Dhawan, S., Hilbers, F. W., Boon, L., Wolkers, M. C., et al. (2014). Adrenergic $\beta 2$ receptor activation stimulates antiinflammatory properties of dendritic cells in vitro. PLoS ONE 9:e85086. doi: 10.1371/journal.pone.0085086

Noris, M., and Remuzzi, G. (2013). Overview of complement activation and regulation. Semin. Nephrol. 33, 479-492. doi: 10.1016/j.semnephrol.2013.08.001

O’Reilly, S. (2014). Innate immunity in systemic sclerosis pathogenesis. Clin. Sci. 126, 329-337. doi: 10.1042/CS20130367

Page, G. G., and Ben-Eliyahu, S. (2000). Natural killer cell activity and resistance to tumor metastasis in prepubescent rats: deficient baselines, but invulnerability to stress and beta-adrenergic stimulation. Neuroimmunomodulation 7, 160-168. doi: $10.1159 / 000026434$

Page, G. G., Fennelly, A. M., Littleton-Kearney, M. T., and Ben-Eliyahu, S. (2008). Male-female differences in the impact of beta-adrenoceptor stimulation on resistance to experimental metastasis: exploring the effects of age and gonadal hormone involvement. J. Neuroimmunol. 193, 113-119. doi: 10.1016/j.jneuroim.2007.10.023

Panina-Bordignon, P., Mazzeo, D., Lucia, P. D., D’Ambrosio, D., Lang, R., Fabbri, L., et al. (1997). Beta2-agonists prevent Th1 development by selective inhibition of interleukin 12. J. Clin. Invest. 100, 1513-1519.

Paul-Eugène, N., Kolb, J. P., Calenda, A., Gordon, J., Kikutani, H., Kishimoto, T., et al. (1993). Functional interaction between beta 2-adrenoceptor agonists and interleukin- 4 in the regulation of CD23 expression and release and $\operatorname{IgE}$ production in human. Mol. Immunol. 30, 157-164.

Paul-Eugène, N., Kolb, J. P., Abadie, A., Gordon, J., Delespesse, G., Sarfati, M., et al. (1992). Ligation of CD23 triggers cAMP generation and release of inflammatory mediators in human monocytes. J. Immunol. 149, 3066-3071.

Paul-Eugène, N., Kolb, J. P., Damais, C., Abadie, A., Mencia-Huerta, J. M., Braquet, P., et al. (1994). Beta 2-adrenoceptor agonists regulate the IL-4induced phenotypical changes and IgE-dependent functions in normal human monocytes. J. Leukoc. Biol. 55, 313-320.

Pedersen, P., Hasselgren, P. O., Angerås, U., Hall-Angerås, M., Warner, B. W., LaFrance, R., et al. (1989). Protein synthesis in liver following infusion of the catabolic hormones corticosterone, epinephrine, and glucagon in rats. Metabolism 38, 927-932. doi: 10.1016/0026-0495(89)90001-2

Pohl, A., Otto, J., and Urbanek, R. (1991). Beta-2-adrenoceptors of polymorphonuclear leukocytes in children with atopic dermatitis. Their number and affinity to the radioligand [125I]-cyanopindolol. Int. Arch. Allergy Appl. Immunol. 95, 261-265. doi: 10.1159/000235439

Powe, D. G., Voss, M. J., Zänker, K. S., Habashy, H. O., Green, A. R., Ellis, I. O., et al. (2010). Beta-blocker drug therapy reduces secondary cancer formation in breast cancer and improves cancer specific survival. Oncotarget 1, 628-638.

Prey, S., Leaute-Labreze, C., Pain, C., Moisan, F., Vergnesm, P., Loot, M., et al. (2014). Mast cells as possible targets of propranolol therapy: an immunohistological study of beta-adrenergic receptors in infantile haemangiomas. Histopathology 65, 436-439. doi: 10.1111/his.12421

Prösch, S., Wendt, C. E., Reinke, P., Priemer, C., Oppert, M., Krüger, D. H., et al. (2000). A novel link between stress and human cytomegalovirus (HCMV) infection: sympathetic hyperactivity stimulates HCMV activation. Virology 272, 357-365. doi: 10.1006/viro.2000.0367

Radojcic, T., Baird, S., Darko, D., Smith, D., and Bulloch, K. (1991). Changes in beta-adrenergic receptor distribution on immunocytes during differentiation: an analysis of T cells and macrophages. J. Neurosci. Res. 30, 328-335.

Rainer, T. H., Lam, N., and Cocks, R. A. (1999). Adrenaline upregulates monocyte L-selectin in vitro. Resuscitation 43, 47-55.

Ramsay, C. E., Hayden, C. M., Tiller, K. J., Burton, P. R., Hagel, I., Palenque, M., et al. (1999). Association of polymorphisms in the beta2-adrenoreceptor gene with higher levels of parasitic infection. Hum. Genet. 104, 269-274. doi: $10.1007 /$ s004390050947

Ratge, D., Wiedemann, A., Kohse, K. P., and Wisser, H. (1988). Alterations of betaadrenoceptors on human leukocyte subsets induced by dynamic exercise: effect of prednisone. Clin. Exp. Pharmacol. Physiol. 15, 43-53. doi: 10.1111/j.14401681.1988.tb01007.x 
Riepl, B., Grässel, S., Wiest, R., Fleck, M., and Straub, R. H. (2010). Tumor necrosis factor and norepinephrine lower the levels of human neutrophil peptides 1-3 secretion by mixed synovial tissue cultures in osteoarthritis and rheumatoid arthritis. Arthritis Res. Ther. 12, R110. doi: 10.1186/ar3044

Rosenne, E., Sorski, L., Shaashua, L., Neeman, E., Matzner, P., Levi, B., et al. (2014). In vivo suppression of $\mathrm{NK}$ cell cytotoxicity by stress and surgery: glucocorticoids have a minor role compared to catecholamines and prostaglandins. Brain Behav. Immun. 37:207-219. doi: 10.1016/j.bbi.2013.12.007

Rouppe van der Voort, C., Kavelaars, A., van de Pol, M., and Heijnen, C. J. (1999). Neuroendocrine mediators up-regulate alphalb- and alphaldadrenergic receptor subtypes in human monocytes. J. Neuroimmunol. 95, 165-173. doi: 10.1016/S0165-5728(99)00011-9

Rouppe van der Voort, C., Kavelaars, A., van de Pol, M., and Heijnen, C. J. (2000). Noradrenaline induces the phosphorylation of ERK-2 in human peripheral blood mononuclear cells after induction of $\alpha 1$-adrenergic receptors. J. Neuroimmunol. 108, 82-91. doi: 10.1016/s0165-5728(00)00253-8

Sarigianni, M., Bekiari, E., Tsapas, A., Konstantinidis, D., Kaloyianni, M., Koliakos, G., et al. (2011). Effect of epinephrine and insulin resistance on human monocytes obtained from lean and obese healthy participants: a pilot study. Angiology 62, 38-45. doi: 10.1177/0003319710371616

Saxena, M., and Yeretssian, G. (2014). NOD-Like receptors: master regulators of inflammation and cancer. Front. Immunol. 5:327. doi: 10.3389/fimmu.2014.00327

Scanzano, A., Schembri, L., Rasini, E., Luini, A., Dallatorre, J., Legnaro, M., et al. (2015). Adrenergic modulation of migration, CD11b and CD18 expression, ROS and interleukin-8 production by human polymorphonuclear leukocytes. Inflamm. Res. 64, 127-135. doi: 10.1007/s00011-014-0791-8

Schedlowski, M., Hosch, W., Oberbeck, R., Benschop, R. J., Jacobs, R., Raab, H. R., et al. (1996). Catecholamines modulate human NK cell circulation and function via spleen-independent beta 2-adrenergic mechanisms. J. Immunol. 156, 93-99.

Schopf, R. E., and Lemmel, E. M. (1983). Control of the production of oxygen intermediates of human polymorphonuclear leukocytes and monocytes by beta-adrenergic receptors. J. Immunopharmacol. 5, 203-216. doi: 10.3109/08923978309039106

Schulze, W., and Fu, M. L. (1996). Localization of alpha 1-adrenoceptors in rat and human hearts by immunocytochemistry. Mol. Cell. Biochem. 163-164, 159-165. doi: 10.1007/BF00408653

Schupf, N., Williams, C. A., Berkman, A., Cattell, W. S., and Kerper, L. (1989). Binding specificity and presynaptic action of anaphylatoxin C5a in rat brain. Brain Behav. Immun. 3, 28-38. doi: 10.1016/0889-1591(89) 90003-2

Schwab, K. O., Bartels, H., Martin, C., and Leichtenschlag, E. M. (1993). Decreased beta 2-adrenoceptor density and decreased isoproterenol induced c-AMP increase in juvenile type I diabetes mellitus: an additional cause of severe hypoglycaemia in childhood diabetes? Eur. J. Pediatr. 152, 797-801. doi: 10.1007/BF02073373

Serbina, N. V., Jia, T., Hohl, T. M., and Pamer, E. G. (2008). Monocyte-mediated defense against microbial pathogens. Annu. Rev. Immunol. 26, 421. doi: 10.1146/annurev.immunol.26.021607.090326

Shah, S. M., Carey, I. M., Owen, C. G., Harris, T., Dewilde, S., and Cook, D. G. (2011). Does $\beta$-adrenoceptor blocker therapy improve cancer survival? Findings from a population-based retrospective cohort study. Br. J. Clin. Pharmacol. 72, 157-161. doi: 10.1111/j.1365-2125.2011.03980.x

Shakhar, G., and Ben-Eliyahu, S. (1998). In vivo beta-adrenergic stimulation suppresses natural killer activity and compromises resistance to tumor metastasis in rats. J. Immunol. 160, 3251-3258.

Sloan, E. K., Priceman, S. J., Cox, B. F., Yu, S., Pimentel, M. A., Tangkanangnukul, V., et al. (2010). The sympathetic nervous system induces a metastatic switch in primary breast cancer. Cancer Res. 70, 7042-7052. doi: 10.1158/00085472.CAN-10-0522

Sofroniew, M. V., and Vinters, H. V. (2010). Astrcotys: biology and pathology. Acta Neuropathol. 119, 7-35. doi: 10.1007/s00401-009-0619-8

Speidl, W. S., Toller, W. G., Kaun, C., Weiss, T. W., Pfaffenberger, S., Kastl, S. P., et al. (2004). Catecholamines potentiate LPS-induced expression of MMP1 and MMP-9 in human monocytes and in the human monocytic cell line U937: possible implications for peri-operative plaque instability. FASEB J. 18, 603-605. doi: 10.1096/fj.03-0454fje
Spencer, H., Karavolos, M. H., Bulmer, D. M., Aldridge, P., Chhabra, S. R., Winzer, $\mathrm{K}$., et al. (2010). Genome-wide transposon mutagenesis identifies a role for host neuroendocrine stress hormones in regulating the expression of virulence genes in Salmonella. J. Bacteriol. 192, 714-724. doi: 10.1128/JB.01329-09

Spengler, R. N., Chensue, S. W., Giacherio, D. A., Blenk, N., and Kunkel, S. L. (1994). Endogenous norepinephrine regulates tumor necrosis factor-alpha production from macrophages in vitro. J. Immunol. 152, 3024-3031.

Spits, H., Artis, D., Colonna, M., Diefenbach, A., Di Santo, J. P., Eberl, G., et al. (2013). Innate lymphoid cells-a proposal for uniform nomenclature. Nat. Rev. Immunol. 13, 145-149. doi: 10.1038/nri3365

Spooren, A., Mestdagh, P., Rondou, P., Kolmus, K., Haegeman, G., and Gerlo, S. (2011). IL-1 $\beta$ potently stabilizes IL- 6 mRNA in human astrocytes. Biochem. Pharmacol. 81, 1004-1015. doi: 10.1016/j.bcp.2011.01.019

Stefanski, V., and Ben-Eliyahu, S. (1996). Social confrontation and tumor metastasis in rats: defeat and beta-adrenergic mechanisms. Physiol. Behav. 60, 277-282.

Straub, R. H. (2004). Complexity of the bi-directional neuroimmune junction in the spleen. Trends Pharmacol. Sci. 25, 640-646. doi: 10.1016/j.tips.2004.10.007

Suchánek, O., Podrazil, M., Fischerová, B., Boèínská, H., Budínskı, V., Stejskal, D., et al. (2010). Intensive physical activity increases peripheral blood dendritic cells. Cell. Immunol. 266, 40-45. doi: 10.1016/j.cellimm.2010.08.010

Swirski, F. K., and Nahrendorf, M. (2013). Leukocyte behavior in atherosclerosis, myocardial infarction, and heart failure. Science 339, 161-166. doi: $10.1126 /$ science. 1230719

Szelenyi, J., Selmeczy, Z., Brozik, A., Medgyesi, D., and Magocsi, M. (2006). Dual beta-adrenergic modulation in the immune system: stimulus-dependent effect of isoproterenol on MAPK activation and inflammatory mediator production in macrophages. Neurochem. Int. 49, 94-103. doi: 10.1016/j.neuint.2006.01.009

Tachibana, A., Kato, M., Kimura, H., Fujiu, T., Suzuki, M., and Morikawa, A. (2002). Inhibition by fenoterol of human eosinophil functions including beta2adrenoceptor-independent actions. Clin. Exp. Immunol. 130, 415-423. doi: 10.1046/j.1365-2249.2002.01997.x

Takahashi, H. K., Morichika, T., Iwagaki, H., Yoshino, T., Tamura, R., Saito, S., et al. (2003). Effect of beta 2-adrenergic receptor stimulation on interleukin-18induced intercellular adhesion molecule-1 expression and cytokine production. J. Pharmacol. Exp. Ther. 304, 634-642. doi: 10.1124/jpet.102.042622

Takamoto, T., Hori, Y., Koga, Y., Toshima, H., Hara, A., and Yokoyama, M. M. (1991). Norepinephrine inhibits human natural killer cell activity in vitro. Int. J. Neurosci. 58, 127-131.

Tarr, A. J., Powell, N. D., Reader, B. F., Bhave, N. S., Roloson, A. L., Carson, W. E. III, et al. (2012). $\beta$-Adrenergic receptor mediated increases in activation and function of natural killer cells following repeated social disruption. Brain Behav. Immun. 26, 1226-1238. doi: 10.1016/j.bbi.2012.07.002

Theorell, J., Gustavsson, A. L., Tesi, B., Sigmundsson, K., Ljunggren, H. G., Lundbäck, T., et al. (2014). Immunomodulatory activity of commonly used drugs on Fc-receptor-mediated human natural killer cell activation. Cancer Immunol. Immunother. 63, 627-641. doi: 10.1007/s00262-014-1539-6

Tomozawa, Y., Yabuuchi, K., Inoue, T., and Satoh, M. (1995). Participation of cAMP and cAMP-dependent protein kinase in beta-adrenoceptor-mediated interleukin-1 beta mRNA induction in cultured microglia. Neurosci. Res. 22, 399-409. doi: 10.1016/0168-0102(95)00922-G

Trabold, B., Lunz, D., Gruber, M., Fröhlich, D., and Graf, B. (2010). Immunomodulation of neutrophil-endothelial interaction by inotropes. Injury 41, 1079-1083. doi: 10.1016/j.injury.2010.05.034

Ueshima, H., Inada, T., and Shingu, K. (2013). Suppression of phagosome proteolysis and Matrigel migration with the $\alpha 2$-adrenergic receptor agonist dexmedetomidine in murine dendritic cells. Immunopharmacol. Immunotoxicol. 35, 558-566. doi: 10.3109/08923973.2013.822509

Vago, T., Norbiato, G., Baldi, G., Chebat, E., Bertora, P., and Bevilacqua, M. (1990). Respiratory-burst stimulants desensitize beta-2 adrenoceptors on human polymorphonuclear leukocytes. Int. J. Tissue React. 12, 53-58.

Vasin, M. V., and Kuznetsova, L. N. (1995). Change in the functional activity of the blood complement system after administration of adrenaline to animals. Patol. Fiziol. Eksp. Ter. 3, 16-18.

Wahle, M., Greulich, T., Baerwald, C. G., Häntzschel, H., and Kaufmann, A. (2005). Influence of catecholamines on cytokine production and expression of adhesion molecules of human neutrophils in vitro. Immunobiology 210, 43-52. doi: 10.1016/j.imbio.2005.02.004 
Wallace, L. J., Partlow, L. M., Ellis, M. E., and Woodbury, D. M. (1976). Alphaadrenergic regulation of the secretion of an anticomplementary factor in mouse saliva. Proc. Soc. Exp. Biol. Med. 152, 99-104. doi: 10.3181/00379727-15239337

Wang, J., Li, J., Sheng, X., Zhao, H., Cao, X. D., Wang, Y. Q., et al. (2010). Beta-adrenoceptor mediated surgery-induced production of proinflammatory cytokines in rat microglia cells. J. Neuroimmunol. 223, 77-83. doi: 10.1016/j.jneuroim.2010.04.006

Wang, X. S., and Lau, H. Y. (2006). Beta-adrenoceptor-mediated inhibition of mediator release from human peripheral blood-derived mast cells. Clin. Exp. Pharmacol. Physiol. 33, 746-750. doi: 10.1111/j.1440-1681.2006.04435.x

Whalen, M. M., and Bankhurst, A. D. (1990). Effects of beta-adrenergic receptor activation, cholera toxin and forskolin on human natural killer cell function. Biochem. J. 272, 327-331.

Williams, C. A., Schupf, N., and Hugli, T. E. (1985). Anaphylatoxin C5a modulation of an alpha-adrenergic receptor system in the rat hypothalamus. J. Neuroimmunol. 9, 29-40. doi: 10.1016/S0165-5728(85) 80004-7

Wrona, D. (2006). Neural-immune interactions: an integrative view of the bidirectional relationship between the brain and immune systems. J. Neuroimmunol. 172, 38-58. doi: 10.1016/j.jneuroim.2005.10.017

Xiao, J., Huang, H. W., Peng, Y. P., Bao, J. Y., Huang, Y., and Qiu, Y. H. (2010). Modulation of natural killer cell function by alpha-adrenoreceptor-coupled signalling. Neuro Endocrinol. Lett. 31, 635-644.

Xu, B., Zhang, W. S., Yang, J. L., Lũ, N., Deng, X. M., Xu, H., et al. (2010). Evidence for suppression of spinal glial activation by dexmedetomidine in a rat model of monoarthritis. Clin. Exp. Pharmacol. Physiol. 37, e158-e166. doi: 10.1111/j.1440-1681.2010.05426.x

Xu, Z., Hirasawa, A., Shinoura, H., and Tsujimoto, G. (1999). Interaction of the alpha(1B)-adrenergic receptor with $\mathrm{gClq}-\mathrm{R}$, a multifunctional protein. J. Biol. Chem. 274, 21149-21154. doi: 10.1074/jbc.274.30.21149

Yanagawa, Y., Matsumoto, M., and Togashi, H. (2010). Enhanced dendritic cell antigen uptake via alpha2 adrenoceptor-mediated PI3K activation following brief exposure to noradrenaline. J. Immunol. 185, 5762-5768. doi: 10.4049/jimmunol.1001899
Yanagawa, Y., Matsumoto, M., and Togashi, H. (2011). Adrenoceptor-mediated enhancement of interleukin-33 production by dendritic cells. Brain Behav. Immun. 25, 1427-1433. doi: 10.1016/j.bbi.2011.04.012

Yang, H., Du, R. Z., Qiu, J. P., Tang, Y. Q., and Chen, S. C. (2013). Bisoprolol reverses epinephrine-mediated inhibition of cell emigration through increases in the expression of $\beta$-arrestin 2 and CCR7 and PI3K phosphorylation, in dendritic cells loaded with cholesterol. Thromb. Res. 131, 230-237. doi: 10.1016/j.thromres.2012.12.009

Yang, J. H., Lee, E. O., Kim, S. E., Suh, Y. H., and Chong, Y. H. (2012). Norepinephrine differentially modulates the innate inflammatory response provoked by amyloid- $\beta$ peptide via action at $\beta$-adrenoceptors and activation of cAMP/PKA pathway in human THP-1 macrophages. Exp. Neurol. 236, 199-206. doi: 10.1016/j.expneurol.2012.05.008

Yokoyama, W. M. (2005). Natural killer cell immune responses. Immunol. Res. 32, 317-325. doi: 10.1385/IR:32:1-3:317

Yona, S., Kim, K. W., Wolf, Y., Mildner, A., Varol, D., Breker, M., et al. (2013). Fate mapping reveals origins and dynamics of monocytes and tissue macrophages under homeostasis. Immunity 38, 79-91. doi: 10.1016/j.immuni.2012.12.001

Yukawa, T., Ukena, D., Kroegel, C., Chanez, P., Dent, G., Chung, K. F., et al. (1990). Beta 2-adrenergic receptors on eosinophils. Binding and functional studies. Am. Rev. Respir. Dis. 141, 1446-1452. doi: 10.1164/ajrccm/141.6.1446

Zeinstra, E., Wilczak, N., and De Keyser, J. (2000). [3H]dihydroalprenolol binding to beta adrenergic receptors in multiple sclerosis brain. Neurosci. Lett. 289, 75-77. doi: 10.1016/S0304-3940(00)01254-4

Conflict of Interest Statement: The authors declare that the research was conducted in the absence of any commercial or financial relationships that could be construed as a potential conflict of interest.

Copyright (C) 2015 Scanzano and Cosentino. This is an open-access article distributed under the terms of the Creative Commons Attribution License (CC BY). The use, distribution or reproduction in other forums is permitted, provided the original author(s) or licensor are credited and that the original publication in this journal is cited, in accordance with accepted academic practice. No use, distribution or reproduction is permitted which does not comply with these terms. 